\title{
Prostacyclin primes pregnant human myometrium for an enhanced contractile response in parturition
}

\author{
Kristina M. Fetalvero, ${ }^{1,2}$ Peisheng Zhang, ${ }^{3,4}$ Maureen Shyu, ${ }^{1}$ Benjamin T. Young, ${ }^{3,4}$ \\ John Hwa, ${ }^{2,5}$ Roger C. Young, ${ }^{3,4}$ and Kathleen A. Martin ${ }^{1,2}$ \\ ${ }^{1}$ Department of Surgery, ${ }^{2}$ Department of Pharmacology and Toxicology, ${ }^{3}$ Department of Physiology, \\ ${ }^{4}$ Section of Obstetrics and Gynecology, Department of Medicine, and ${ }^{5}$ Section of Cardiology, Department of Medicine, \\ Dartmouth Medical School, Dartmouth-Hitchcock Medical Center, Lebanon, New Hampshire, USA.
}

\begin{abstract}
An incomplete understanding of the molecular events that regulate the myometrial transition from the quiescent pregnant state to the active contractile state during labor has hindered the development of improved therapies for preterm labor. During myometrial activation, proteins that prime the smooth muscle for contraction are upregulated, allowing maximal responsiveness to contractile agonists and thereby producing strong phasic contractions. Upregulation of one such protein, COX-2, generates PGs that induce contractions. Intriguingly, the predominant myometrial $\mathrm{PG}$ produced just prior to labor is prostacyclin $\left(\mathrm{PGI}_{2}\right)$, a smooth muscle relaxant. However, here we have shown that activation of $\mathrm{PGI}_{2}$ receptor (IP) upregulated the expression of several contractile proteins and the gap junction protein connexin 43 through cAMP/PKA signaling in human myometrial tissue in organ and cell culture. Functionally, these IP-dependent changes in gene expression promoted an enhanced contractile response to oxytocin in pregnant human myometrial tissue strips, which was inhibited by the IP antagonist RO3244794. Furthermore, contractile protein induction was dependent on the concentration and time of exposure to the PGI 2 analog iloprost and was blocked by both RO3244794 and PKA knockdown. We therefore propose that $\mathrm{PGI}_{2}$-mediated upregulation of contractile proteins and connexin 43 is a critical step in myometrial activation, allowing for a maximal contractile response. Our observations have important implications regarding activation of the myometrium prior to the onset of labor.
\end{abstract}

\section{Introduction}

Prior to initiation of term labor, the myometrium must become activated (1). This term refers to the conversion of the uterus from an inactive, quiescent physiological state to one capable of exhibiting strong phasic contractions. Early signals, such as expression of surfactant protein A (2) and corticotropin-releasing hormone (3-5), originate with the fetus and placenta, respectively, and, after many intermediate steps, ultimately lead to myometrial activation. The mechanisms and signaling pathways, however, remain poorly understood. Critically absent is knowledge about the signals and cellular mechanisms that directly lead to myometrial activation.

Activation enables the myometrium to be sensitive to contractile stimuli, such as oxytocin and PGs, and to generate synchronous and frequent contractions during labor (1). For smooth muscle cells to become responsive to these agonists, the coordinated expression of several contraction-associated proteins must occur $(1,6,7)$. Contraction-associated proteins - which include the oxytocin receptor, $\mathrm{PG}$ receptors, $\mathrm{COX}-2$, ion channels, and gap junction proteins, in particular connexin 43 - promote myometrial cell contractility and excitability as well as intracellular connectivity. Gap junctions are present at very low levels during pregnancy, but gap junction proteins, connexin 43 in particular, increase in myometrial cells during labor and delivery (8-10).

Nonstandard abbreviations used: $\mathrm{IP}, \mathrm{PGI}_{2}$ receptor; $\mathrm{PDH}$, pyruvate dehydrogenase; $\mathrm{PGI}_{2}$, prostacyclin; SM-MHC, smooth muscle myosin heavy chain; SM2-MHC, SM-MHC isoform 2; uSMC, uterine SMC.

Conflict of interest: The authors have declared that no conflict of interest exists. Citation for this article: J. Clin. Invest. doi:10.1172/JCI33800.
Notably, mice with smooth muscle-specific deletion of connexin 43 had a significantly prolonged birth process, which suggests that connexin 43 is necessary for the initiation and progression of labor (11). Also important for myometrial activation are the proteins that make up the contractile apparatus, including the thick filament-associated protein smooth muscle myosin heavy chain (SM-MHC) and the thin filament-associated proteins $\alpha$-SMA, calponin, and h-caldesmon $(7,12)$. Actin and myosin are the principal interacting structural proteins that generate myocyte contractility. Others, including calponin and h-caldesmon, modulate the actomyosin complex $(13,14)$. Previous studies have shown that expression levels of contractile apparatus proteins increase with pregnancy (15-17).

Preterm delivery complicates $12 \%-13 \%$ of pregnancies (18) and remains the leading cause of neonatal mortality and morbidity, including increased risk of neurological and developmental complications (19). Spontaneous labor prior to term accounts for a substantial proportion of these preterm births. Understanding the molecular events that regulate this process is essential in order to develop better therapies for inhibiting preterm labor. Despite the use of tocolytic therapy, the occurrence of preterm labor has continued to rise (19). Thus, an understanding of the molecular processes that regulate labor is necessary to develop better strategies to prevent preterm labor and to more effectively induce labor when necessary.

PGs, a family of arachidonic acid-derived lipids, are known to regulate myometrial stimulation $(20,21) . \mathrm{PGF}_{2 \alpha}$ and, to a lesser extent, $\mathrm{PGE}_{2}$ directly stimulate uterine contractility in vitro (22-25). In human pregnancy, PGs are produced by the amnion and chori- 


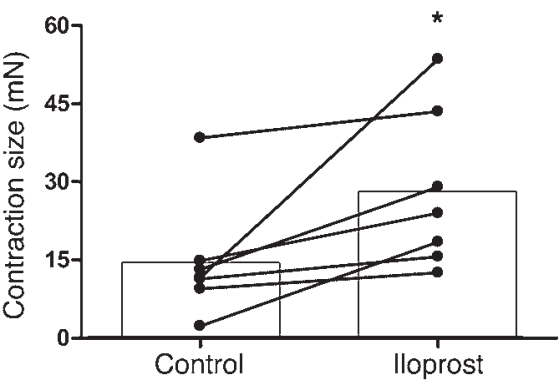

Figure 1

Iloprost enhances oxytocin-induced contractility in human myometrial tissue. Human myometrial tissue strips were suspended vertically under $400 \mathrm{mg}$ tension in DMEM plus 10\% FBS. Tissue was treated with vehicle (control) or $25 \mathrm{nmol} / \mathrm{l}$ iloprost for $48 \mathrm{~h}$, then transferred to an isometric muscle bath and treated with $5 \mathrm{nmol} / \mathrm{l}$ oxytocin as described in Methods. Average peak contraction force in response to oxytocin in paired tissue strips is plotted from 7 independent experiments. Arithmetic mean values are represented by bars, and individual measurements are plotted for the 7 patient samples. ${ }^{\star} P<0.05$ versus control, Mann-Whitney $U$ test.

on, the decidua, and the myometrium (20). Interestingly, the most highly synthesized PG produced by the pregnant human myometrium is prostacyclin $\left(\mathrm{PGI}_{2}\right)(26-29)$. This presents as a paradox, because while its synthesis is increased prior to and during labor $(27,30,31), \mathrm{PGI}_{2}$ is known to be a potent smooth muscle relaxant (32). $\mathrm{PGI}_{2}$ signals predominantly through the cell surface $\mathrm{G}$ protein-coupled human $\mathrm{PGI}_{2}$ receptor $(\mathrm{hIP})(33,34)$, which activates $\mathrm{G}_{\alpha \mathrm{s}}$ and adenylyl cyclase to induce the second messenger cAMP, which activates PKA (33-35). The relaxing effects of $\mathrm{PGI}_{2}$ have been attributed to activation of this pathway.

Many potential physiologic roles for the relaxant effects of $\mathrm{PGI}_{2}$ during labor have been proposed. For example, it has been speculated that $\mathrm{PGI}_{2}$ may prevent overstimulation of myometrial cells at the time of labor (36) or may play a role in cervical softening (21). It has also been suggested that because $\mathrm{PGI}_{2}$ has potent vasodilatory $(37,38)$ and antiplatelet activity $(39)$, it may be important for preventing intrapartum thromboembolic complications in the maternal and fetoplacental circulation (31). Others have suggested that $\mathrm{PGI}_{2}$ may actually promote myometrial contractility instead of relaxation. Previous studies in tissue strips from nonpregnant (40) and pregnant (41) rat myometrium demonstrated that acute exposure to $\mathrm{PGI}_{2}$ leads to contractile activity. However, studies performed on pregnant human myometrial tissue strips have been conflicting, showing either an inhibitory $(28,42)$ or a biphasic effect $(42,43)$ of acute $\mathrm{PGI}_{2}$ or $\mathrm{PGI}_{2}$ analog treatment on contractions.

It is also possible that in addition to acute effects, $\mathrm{PGI}_{2}$ may cause longer-range effects at the level of gene expression. We have previously reported that $\mathrm{PGI}_{2}$ induces contractile protein expression in human VSMCs (44). Because the physiologic role of $\mathrm{PGI}_{2}$ in myometrial activation and labor is poorly understood, and because of the potential importance to preterm labor prevention, we sought to determine whether $\mathrm{PGI}_{2}$ induces changes in contractile apparatus protein or connexin 43 gene expression and functional contractility in pregnant human myometrium. We report that $\mathrm{PGI}_{2}$ signaling through PKA upregulated connexin 43 and contractile protein expression and enhanced the contractile response in pregnant human myometrial tissue.

\section{Results}

Iloprost enhances the contractile response of uterine tissue to oxytocin. It has been reported that levels of $\mathrm{PGI}_{2}$ increase prior to labor, between weeks 38 and 40 (27); however, the physiologic role for $\mathrm{PGI}_{2}$ in labor remains unclear. We previously showed that in vascular smooth muscle, $\mathrm{PGI}_{2}$ induces contractile apparatus proteins, including SM-MHC, $\alpha$-SMA, and calponin (44). In the present study, we aimed to more closely study the effects of $\mathrm{PGI}_{2}$ exposure on human uterine smooth muscle to determine whether $\mathrm{PGI}_{2}$ signaling regulates connexin 43 and contractile apparatus proteins as well as its ability to regulate uterine contractility using an organ culture model. Specimens were obtained from pregnant women undergoing scheduled Caesarian delivery prior to onset of natural labor. We have previously demonstrated that myometrial tissue strips in organ culture under tension maintain spontaneous contractility as well as contractile response to oxytocin for up to 7 days (45). It is worth noting that tissue obtained from the lower uterine segment is known to vary in contractility, likely because of differences in the site of excision from the uterus. To minimize this effect, we performed experiments only on paired tissue strips that were obtained from the same specimen. Tissue strips were cultured in parallel in the presence or absence of the $\mathrm{PGI}_{2}$ analog iloprost for $48 \mathrm{~h}$, after which oxytocin-induced contractions of the tissue strips were measured. Usually, spontaneous contractions were irregular and infrequent when the tissue was initially stabilized in the isometric apparatus. Oxytocin was added to initiate rhythmic contractions and test tissue responsiveness. In each case, tissue responded to oxytocin exposure with increased contraction strength. In tissue samples from each of 7 consecutive consenting patients, iloprost pretreatment resulted in greater oxytocin-induced contractile response compared with its control, but the magnitude of the increase varied from 1.1- to 9-fold (Figure 1). Using the Mann-Whitney $U$ test, we determined that this increase achieved a statistical significance of $P=0.0253474$. These data reveal that long-term pretreatment of myometrial tissue with iloprost promoted an enhanced contractile response to the agonist oxytocin.

Iloprost upregulates contractile apparatus proteins and connexin 43 in uterine tissue. We investigated possible mechanisms underlying the enhanced contractile response to oxytocin induced by iloprost. Prior to labor, a group of proteins referred to as contraction-associated proteins are expressed. These proteins act to initiate powerful synchronous contractions during labor. Also important are contractile proteins such as $\alpha$-SMA and SM-MHC, which determine myocyte contractility. As we have previously shown that $\mathrm{PGI}_{2}$ can induce contractile protein expression in cultured VSMCs (44), we sought to determine whether iloprost increased expression of these proteins in uterine tissue. We subjected some of the tissue strips from the experiments in Figure 1 to Western blot analysis immediately after the contraction assay and observed an increased expression of SM-MHC isoform 2 (SM2-MHC) and calponin in tissue cultured with iloprost relative to PBS vehicle treatment (Figure 2A). This upregulation also occurred after $6 \mathrm{~h}$ of iloprost pretreatment (Figure $2 \mathrm{~B}$ ). To eliminate any potentially confounding effects of oxytocin exposure, we treated myometrial tissue with vehicle or iloprost for 6 or $48 \mathrm{~h}$ and then immediately performed Western analysis. Expression of the contractile proteins $\alpha$-SMA, h-caldesmon, calponin, and SM2-MHC increased in tissue treated with iloprost (Figure 2, C and D). 
A

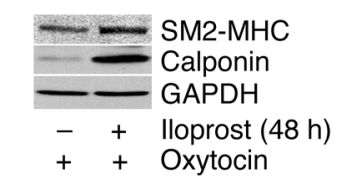

B

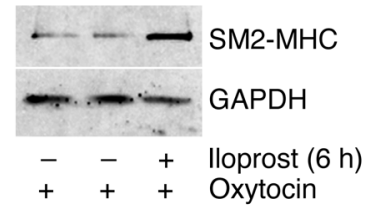

C

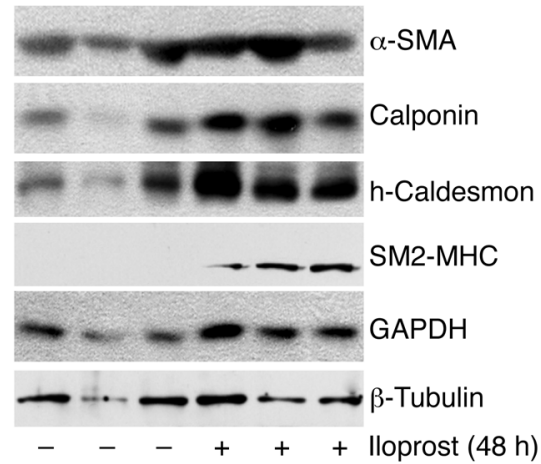

D

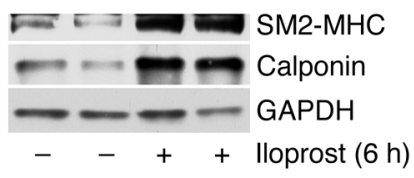

$\mathbf{E}$

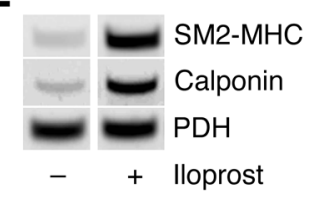

Figure 2

Iloprost upregulates contractile apparatus protein and mRNA expression in human myometrial tissue. (A and B) Human myometrial tissue strips in organ culture were pretreated with $25 \mathrm{nmol} / \mathrm{l}$ iloprost for $(\mathbf{A}) 48 \mathrm{~h}$ or $(\mathbf{B}) 6 \mathrm{~h}$. After contraction assay with $5 \mathrm{nmol} / \mathrm{l}$ oxytocin, protein was isolated from the tissue as described in Methods and subjected to Western blot analysis with antibodies to SM2-MHC (A and B) and calponin (A). GAPDH served as a loading control. (C and D) Protein was isolated from human myometrial tissue in organ culture treated with vehicle or $25 \mathrm{nmol} / \mathrm{I}$ iloprost for (C) $48 \mathrm{~h}$ or (D) $6 \mathrm{~h}$. Cell lysates were subjected to Western blot analysis with antibodies to SM2-MHC and calponin (C and D) as well as $\alpha$-SMA and h-caldesmon (C). (E) Human myometrial tissue strips in organ culture were treated with vehicle or $25 \mathrm{nmol} / \mathrm{l}$ iloprost for $48 \mathrm{~h}$. Total RNA was isolated as described in Methods and subjected to semiquantitative RT-PCR using primers to basic calponin, SM-MHC, and PDH housekeeping gene. Lanes were run on the same gel but were noncontiguous (lines). Data in $\mathbf{A}-\mathbf{E}$ are from 5 individual patients.

To begin to address the mechanisms underlying the enhanced contractile protein expression, we next assessed the effects of iloprost exposure on mRNA levels of calponin and SM-MHC in uterine tissue strips. RT-PCR experiments were performed after $48 \mathrm{~h}$ of exposure to iloprost or vehicle. Calponin and SM-MHC mRNA levels were increased, which suggests that iloprost may regulate contractile protein expression at the level of transcription (Figure 2E).

Given the important role of gap junctions and connexin 43 in myometrial contractility and labor progression (8-11), we wanted to determine whether iloprost also influences connexin 43 expression in myometrial tissue. Treatment of myometrial tissue with iloprost for $48 \mathrm{~h}$ resulted in a significant increase in connexin 43 expression compared with control (Figure 3 ). Based on previous studies showing the importance of connexin 43 in regulating parturition (11), these data suggest that iloprost may also enhance oxytocin-induced contractility by increasing connexin 43 expression.

Because iloprost at high concentrations can also activate EP1 receptors $(46,47)$, we used a recently developed potent and selective IP antagonist, RO3244794 (48), as a tool to determine the contribution of the hIP in modulating the iloprost-induced enhanced contractile response to oxytocin response. As in Figure 1 , we found that myometrial tissue treated with iloprost for $48 \mathrm{~h}$ demonstrated increased contractile activity in response

\section{Figure 3}

lloprost increases connexin 43 expression. Protein was isolated from human myometrial tissue in organ culture treated with vehicle or $25 \mathrm{nmol} / \mathrm{l}$ iloprost for $48 \mathrm{~h}$. Left: Cell lysates were subjected to Western blot analysis with antibodies to connexin 43 (Cx43) and GAPDH. A representative blot is shown. Right: Densitometric quantitation from 5 independent experiments on samples from 5 different patients. Because connexin 43 is known to migrate as a doublet or triplet spanning the 39- to 44-kDa range, we summed the band intensities for both bands for each sample and corrected the values to the corresponding GAPDH. Results are mean \pm SEM. ${ }^{*} P<0.05$, paired 1 -tailed Student's $t$ test. to oxytocin relative to control-pretreated tissue (Figure 4A). However, pretreatment with iloprost and RO3244794 blocked the iloprost-enhanced uterine activity, which suggests that the increased activity is specific to activation of the hIP. Interestingly, we observed that RO3244794 alone also reduced the response to oxytocin (Figure 4A), which suggests that endogenous $\mathrm{PGI}_{2}$ produced by the tissue while in organ culture contributes to uterine contractility. Sample traces showing basal and iloprostinduced responses to oxytocin in the presence or absence of RO3244794 are shown in Figure 4B. Western blot analysis of the tissue revealed that $\mathrm{RO} 3244794$ also blocked the iloprostinduced increase in h-caldesmon, connexin 43, and SM2-MHC expression (Figure 4, C and D).

In Figure 2, we showed that prolonged iloprost treatment induced contractile protein expression in myometrial tissue whether or not the tissue had been subjected to contraction with oxytocin. In Figure 4D, we further assessed the effects of oxytocin, with and without iloprost. Interestingly, treating tissue with oxytocin alone for $90 \mathrm{~min}$ promoted a modest, but measurable, increase in SM2-MHC protein expression relative to vehicle control. However, treatment with iloprost alone for $48 \mathrm{~h}$ induced
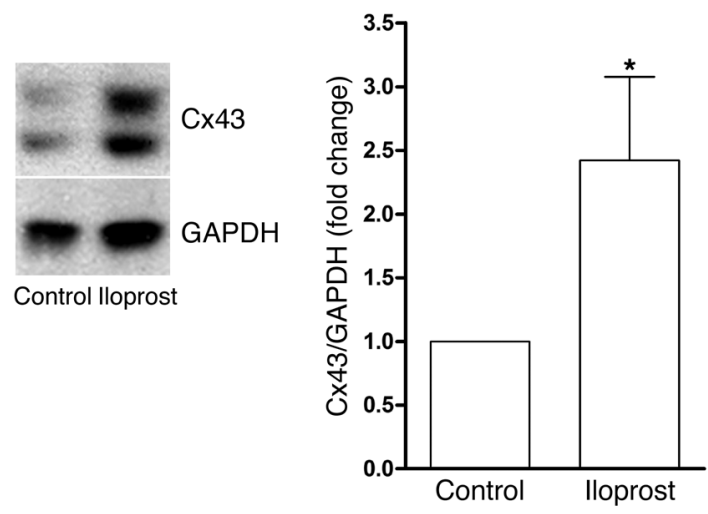
A

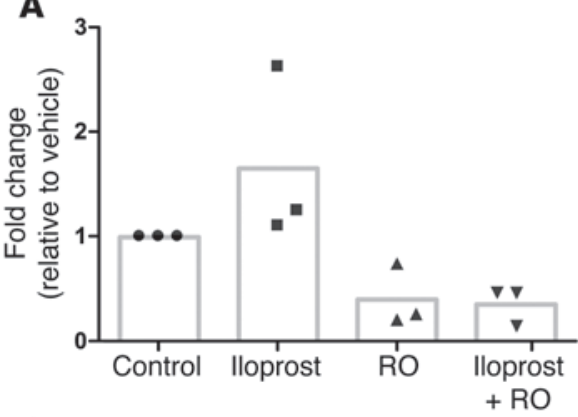

C

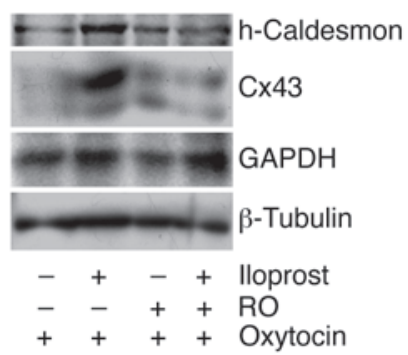

B

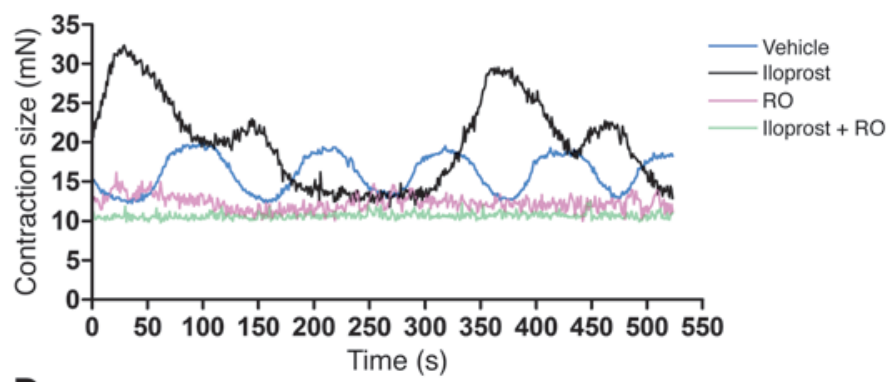

D

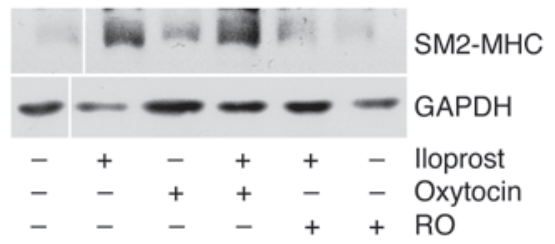

Figure 4

An IP antagonist opposes iloprost-enhanced oxytocin-induced contractions and iloprost-induced contractile protein expression. (A) Human myometrial tissue in organ culture was pretreated with $90 \mu \mathrm{mol} / / \mathrm{RO} 3244794$ (RO) for 30 min and then stimulated with or without $25 \mathrm{nmol} / \mathrm{l}$ iloprost for $48 \mathrm{~h}$, after which tissue was transferred to an isometric muscle bath and treated with $5 \mathrm{nmol} / \mathrm{l}$ oxytocin as described in Methods. Average peak contraction data are represented as fold change relative to vehicle control. Arithmetic mean values are represented by bars, and individual measurements are plotted for the 3 patients. (B) Representative tracings for 1 patient in A. (C) Homogenates of uterine tissue isolated from $\mathbf{A}$ were subjected to Western blot analysis with antibodies to h-caldesmon, connexin 43, GAPDH, or $\beta$-tubulin. (D) Human myometrial tissue in organ culture was pretreated with $90 \mu \mathrm{mol} / \mathrm{l}$ RO3244794 for $30 \mathrm{~min}$ and then treated with vehicle or $25 \mathrm{nmol} / \mathrm{l}$ iloprost for $48 \mathrm{~h}$, followed by treatment with $5 \mathrm{nmol} / \mathrm{l}$ oxytocin for $8 \mathrm{~h}$, as indicated. Protein was isolated from the tissue and subjected to Western blot analysis with antibodies to SM2-MHC or GAPDH. Lanes were run on the same gel but were noncontiguous (lines).

a greater SM2-MHC expression than did oxytocin alone, and the effects appeared to be additive (Figure 4D). Collectively, our data suggest that long-term pretreatment of myometrial tissue with iloprost, acting through the hIP, modifies the properties of the tissue, upregulating contractile protein and gap junction protein expression and resulting in an enhanced contractile response to the agonist oxytocin.

Iloprost induces SMC-specific contractile apparatus proteins and connexin 43 in monolayer cultures of uterine SMCs. To further investigate the molecular mechanisms underlying iloprost-induced contractile protein expression, we used a monolayer primary culture model of human uterine SMCs (uSMCs) in which cells were cultured from patient specimens obtained as described above. First, dose dependence and kinetics of the response were evaluated. Treatment for $6 \mathrm{~h}$ with increasing concentrations of iloprost increased mRNA levels of SM-MHC (Figure 5A). This increase was maximal at $2.5 \mathrm{nmol} / 1$ iloprost and decreased slightly at $100 \mathrm{nmol} / 1$, the highest concentration tested. GPCR desensitization is known to occur after exposure to high concentrations of ligand (49). For this reason, $2.5 \mathrm{nmol} / 1$ iloprost was used in subsequent cell culture studies.

Iloprost induced an accumulation of SM-MHC message as early as $30 \mathrm{~min}$ after treatment, which persisted for up to $18 \mathrm{~h}$ (Figure $5, \mathrm{~B}$ and $\mathrm{C}$ ). To determine whether this induction occurs at the level of transcription, we used the RNA synthesis inhibitor actinomycin D (Figure 5D). After 4 h of treatment with iloprost, there was a 1.5 -fold increase in SM-MHC mRNA, which did not occur in the presence of actinomycin $\mathrm{D}$. These data indicate that the increase in SM-MHC mRNA with iloprost is not the result of enhanced mRNA stability, and it is therefore likely that iloprost regulates SM-MHC message at the level of transcription.

As in the organ culture model, iloprost induced expression of $\alpha$-SMA, calponin, h-caldesmon, and SM2-MHC at the protein level (Figure 6A). This induction showed a concentration dependence similar to that seen at the mRNA level (Figure 5A). This upregulation was also time dependent: protein levels of calponin, h-caldesmon, and SM2-MHC increased as early as $2 \mathrm{~h}$, and were sustained for up to $24 \mathrm{~h}$, after treatment with $2.5 \mathrm{nmol} / \mathrm{l}$ iloprost (Figure 6, B-D). Notably, the increase in SM2-MHC protein closely followed the kinetics of the mRNA induction (Figure 5, B and $\mathrm{C}$, and Figure 6D). Treatment with $2.5 \mathrm{nmol} / \mathrm{l}$ iloprost also increased connexin 43 message and protein levels in a time-dependent manner (Figure 7, A and B).

The cAMP/PKA pathway is necessary for iloprost-induced contractile protein and connexin 43 expression. In direct analogy with vascular smooth muscle (44), we hypothesized that activation of the cAMP/ PKA pathway mediates iloprost-induced contractile apparatus protein expression in uSMCs. Indeed, iloprost induced cAMP accumulation in uSMCs in a concentration-dependent manner, with an $\mathrm{EC}_{50}$ of $12.5 \mathrm{nmol} / 1$ (Figure $8 \mathrm{~A}$ ). The main effector of cAMP, $\mathrm{PKA}$, was activated after $20 \mathrm{~min}$ in a concentration-dependent manner by iloprost, with an $\mathrm{EC}_{50}$ of $18 \mathrm{nmol} / \mathrm{l}$ (Figure $8 \mathrm{~B}$ ). The specific PKA inhibitor peptide PKI inhibited PKA activity induced by $100 \mathrm{nmol} / 1$ iloprost, confirming the specificity of the kinase 
A

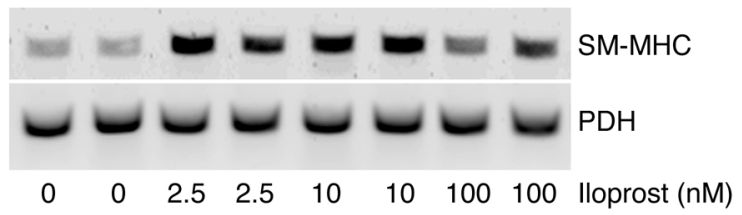

B

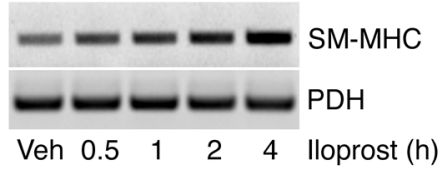

C

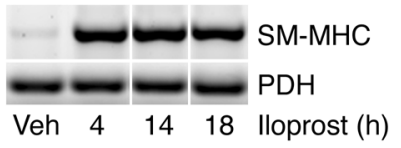

D
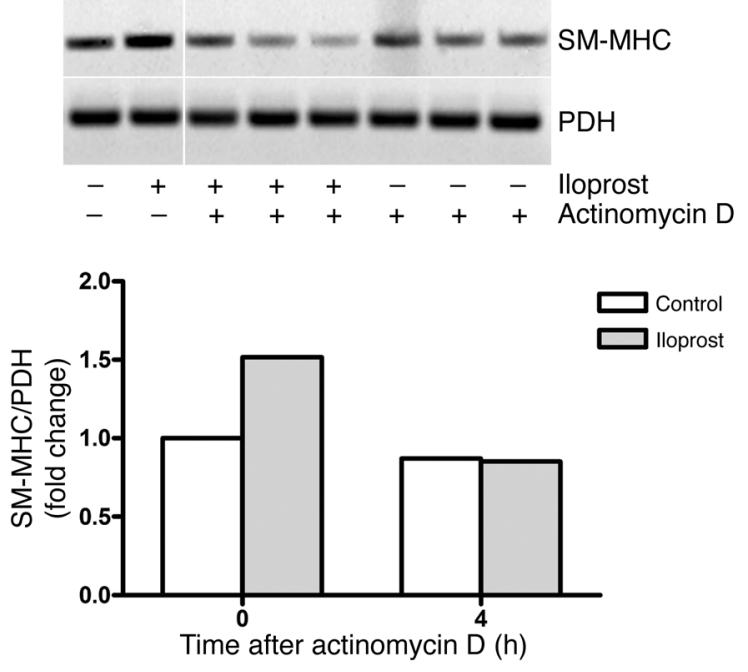

Figure 5

lloprost induces SM-MHC and calponin message in uSMC culture. (A) Human uSMCs were treated with the indicated concentrations of iloprost for $6 \mathrm{~h}$. Total RNA was isolated and subjected to RT-PCR using primers to SM-MHC and PDH. (B and C) Total RNA was isolated from cells treated with vehicle (Veh) or $2.5 \mathrm{nmol} / \mathrm{l}$ iloprost for the indicated times, and RT-PCR was performed as in A. (D) Human uSMCs were treated with vehicle or $2.5 \mathrm{nmol} / \mathrm{l}$ iloprost for $4 \mathrm{~h}$, followed by treatment with $1 \mu \mathrm{g} / \mathrm{ml}$ actinomycin D for an additional $4 \mathrm{~h}$. Total RNA was isolated and subjected to RT-PCR using primers to SM-MHC or PDH. Representative gels are shown, as well as densitometric quantitation of 2 separate experiments below. Arithmetic mean values represent fold induction corrected to $\mathbf{P D H}$. Data in $\mathbf{A}-\mathbf{D}$ were from cell cultures derived from 3 different patients. Lanes in $\mathbf{C}$ and $\mathbf{D}$ were run on the same gel but were noncontiguous (lines).

assay (data not shown). Our assays revealed that iloprost-induced PKA activity was transient, peaking at $20 \mathrm{~min}$ and returning to baseline by $90 \mathrm{~min}$ (Figure 8C).

To verify the role of the cAMP in iloprost-induced expression of contractile proteins, we next determined whether the membranepermeable analog 8-Br-cAMP could mimic the effect of iloprost in uSMCs. Treatment with 8-Br-cAMP resulted in concentrationdependent increases in PKA activity (data not shown). We determined that $0.5 \mu \mathrm{mol} / 1$ 8-Br-cAMP yielded a level of PKA activity similar to that yielded by $2.5 \mathrm{nmol} / 1$ iloprost (2.2- and 1.7 -fold increase over control, respectively; Figure 9A) and induced expression of calponin and SM-MHC mRNA as early as $1 \mathrm{~h}$ (Figure 9B). 8-Br-cAMP increased $\alpha$-SMA, calponin, h-caldesmon, and SM2MHC protein in a concentration-dependent (Figure 9C) and timedependent (Figure 9D) manner, confirming that the second messenger cAMP is sufficient to induce contractile proteins.

To determine whether PKA activation is necessary for the iloprost-induced contractile protein expression, we used siRNA targeted to PKA catalytic subunits to specifically inhibit PKA function. Two highly homologous PKA catalytic subunit isoforms are expressed in uSMCs, PKA catalytic $\alpha$ (PKA C $\alpha$ ) and PKA $\mathrm{C} \beta$. To avoid functional redundancy, we used siRNAs targeting each subunit in combination. Transfection of uSMCs with PKA $\mathrm{C} \alpha$ - and PKA C $\beta$-specific siRNA reduced subunit expression by $53 \%$ and $71 \%$, respectively (Figure 10A), and significantly reduced iloprost-induced PKA activity (Figure 10B). PKA C $\alpha$ and PKA $\mathrm{C} \beta$ knockdown also significantly inhibited the iloprost-induced upregulation of calponin, h-caldesmon, SM2-MHC, and connexin 43 (Figure 10, C-F) proteins to near-control levels. Thus, we conclude that the cAMP/PKA pathway is not only sufficient, but also necessary, for the regulation of contractile protein and connexin 43 expression induced by iloprost.
While these data strongly support a mechanism in which the G protein-coupled hIP induces contractile protein expression by coupling to $\mathrm{G}_{\alpha \mathrm{s}}, \mathrm{cAMP}$, and PKA, we tested 2 alternate possibilities. Iloprost has the potential to activate other prostanoid GPCRs, in particular EP1 $(46,47)$. We found contractile protein induction at low doses of iloprost $\left(2.5 \mathrm{nM}\right.$, below the $\mathrm{EC}_{50}$ for cAMP production), but we also tested another $\mathrm{PGI}_{2}$ analog, cicaprost, which is more specific for hIP (47). Cicaprost activated PKA in a concentration-dependent manner (Figure 11A), and, similar to iloprost, the enhanced activity was transient, peaking at $20 \mathrm{~min}$ and declining by $60 \mathrm{~min}$ (Figure 11B). Cicaprost induced dose-dependent increases in h-caldesmon, $\alpha$-SMA, and SM2-MHC (Figure 11C) and upregulated SM2-MHC, $\alpha$-SMA, calponin, and connexin 43 protein expression in a time-dependent manner (Figure 11, D-F).

Finally, there is also the possibility that $\mathrm{PGI}_{2}$ and its analogs, at higher concentrations, can activate the intracellular receptor PPARd, a transcription factor $(50,51)$. Because we observed effects on contractile protein expression at the level of transcription, we tested whether contractile protein induction was dependent entirely on the hIP cell surface GPCR using RO3244794. RO3244794 inhibited iloprost-induced PKA to baseline levels (Figure 12A) and completely blocked the iloprost induction of h-caldesmon and SM2-MHC (Figure 12, B and C). As a control for receptor specificity, we demonstrated that RO3244794 had no effect on 8-Br-cAMP-induced contractile protein expression (Figure 12D). As demonstrated above, RO3244794 also inhibited contractile protein and connexin 43 expression induced by iloprost in human uterine tissue strips (Figure 4, C and D). Together, these data confirm that iloprost induces contractile protein and connexin 43 expression in uSMCs via the cell surface hIP GPCR and signaling through the cAMP/PKA pathway. 
A

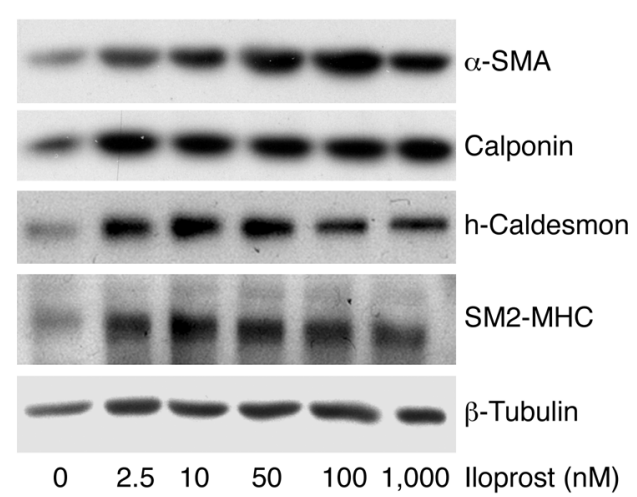

c
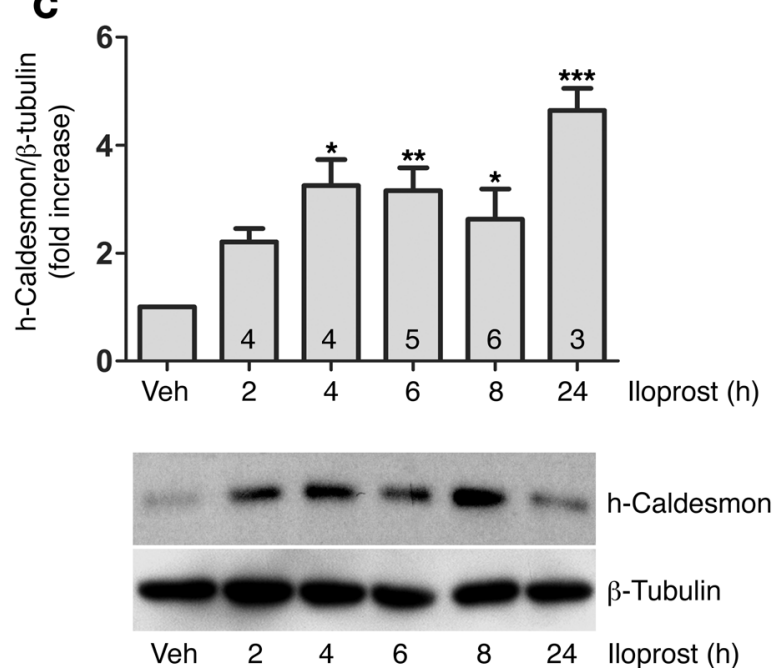

B

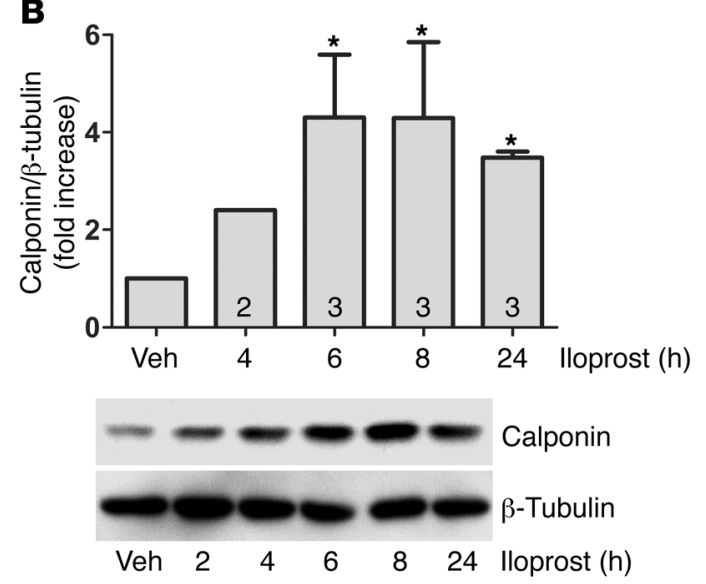

D
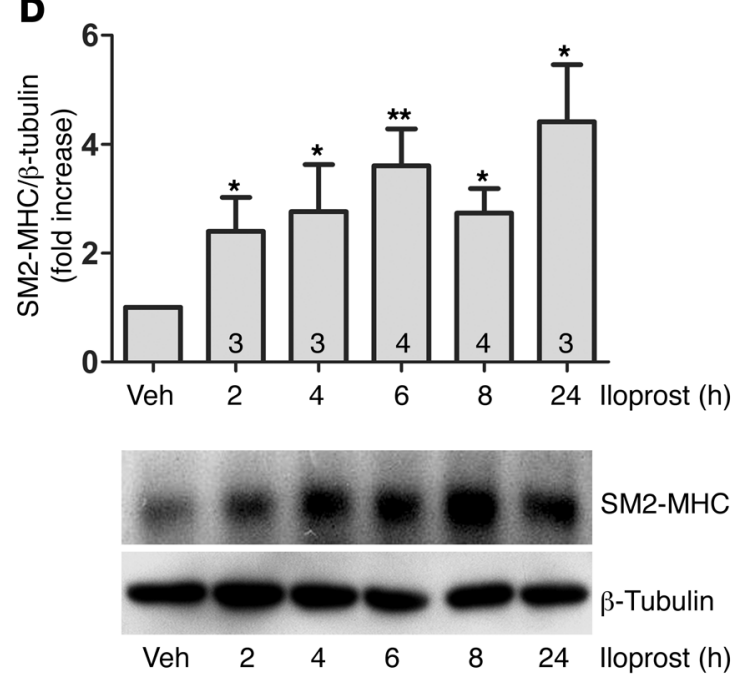

Figure 6

lloprost induces expression of contractile apparatus proteins in human uSMCs. (A) Cell lysates from human uSMCs treated with the indicated concentrations of iloprost for $8 \mathrm{~h}$ were subjected to Western blot analysis with antibodies to $\alpha$-SMA, calponin, h-caldesmon, and SM2-MHC, or $\beta$-tubulin as a loading control. (B-D) Human uSMCs were treated with vehicle or $2.5 \mathrm{nmol} / \mathrm{l}$ iloprost for the indicated times. Cell lysates were subjected to Western blot analysis with antibodies to (B) calponin, (C) h-caldesmon, and (D) SM2-MHC; shown is 1 representative immunoblot for each antibody and quantified protein expression, corrected to $\beta$-tubulin and presented as fold induction in order to average data from multiple experiments. $n$ is indicated for each time point. ${ }^{*} P<0.05,{ }^{* *} P<0.01,{ }^{* *} P<0.001$ versus vehicle, 1 -way ANOVA with Newman-Keuls post-hoc test. Data are mean \pm SEM (where $n \geq 3$ ) and were generated from cell cultures from 2 patients.

$\mathrm{PGI}_{2}$ and iloprost exert similar effects in vitro. Iloprost and cicaprost are useful analogs to model the action of $\mathrm{PGI}_{2}$. However, because they are more stable and can potentially activate other prostanoid receptors depending on the concentration, it is possible that native $\mathrm{PGI}_{2}$ may have different receptor binding properties than these analogs (47). For this reason, we tested the effects of $\mathrm{PGI}_{2}$ itself on human uSMCs. Because $\mathrm{PGI}_{2}$ breaks down more rapidly than do iloprost and cicaprost, we also tested single versus repeated administration of $\mathrm{PGI}_{2}$. We determined that, similar to iloprost, a single administration of $\mathrm{PGI}_{2}$ elicited dose-dependent activation of PKA in uSMCs in culture, assayed 20 min after ligand addition (Figure 13A). Repeated administration of $\mathrm{PGI}_{2}$ every $1.5 \mathrm{~h}$ for $6 \mathrm{~h}$ increased SM2-MHC and calponin expression in a dose-dependent manner (Figure 13B). Administration of $0.6 \mu \mathrm{mol} / 1 \mathrm{PGI}_{2}$ and $2.5 \mathrm{nmol} / 1$ iloprost exhibited similar levels of PKA activation (Figure 13A) and of contractile protein upregulation (Figures 13, B and C). Interestingly, a single treat- ment of $\mathrm{PGI}_{2}$ was sufficient to increase contractile protein and connexin 43 expression in a time-dependent manner, up to $24 \mathrm{~h}$ (Figure 13C). Taken together, our data with $\mathrm{PGI}_{2}$, iloprost, cicaprost, and RO3244794 provide evidence that activation of the hIP modulates the expression of contractile apparatus proteins and the gap junction connexin 43 in cultured uSMCs.

\section{Discussion}

The results of the present study provide evidence that $\mathrm{PGI}_{2}$ plays an important role in priming the uterus for contraction prior to labor, both by enhancing oxytocin-induced contractions by increasing expression of contractile proteins, which are critical in generating the contractile force of labor, and by increasing the expression of the gap junction protein connexin 43, which is critical in allowing myocytes to act synchronously. Results were consistent across all 21 consecutive consenting (nonselected) patients. We believe that these results provide substantial new 
A

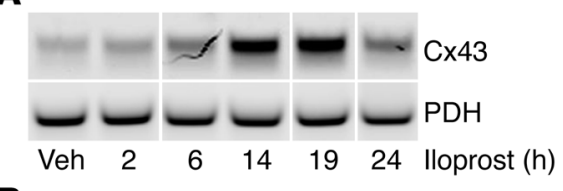

B

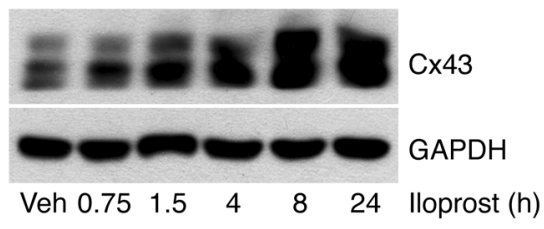

Figure 7

lloprost induces expression of connexin 43 in human uSMCs. (A) Human uSMCs were treated with vehicle or $2.5 \mathrm{nmol} / \mathrm{l}$ iloprost for the indicated times. Total RNA was isolated and subjected to RT-PCR using primers against connexin 43 and $\mathrm{PDH}$. Lanes were run on the same gel but were noncontiguous (lines). (B) Cell lysates from human uSMCs treated with $2.5 \mathrm{nmol} / \mathrm{l}$ iloprost for the indicated times were subjected to Western blot analysis with antibodies to connexin 43 and GAPDH.

insights into the role of $\mathrm{PGI}_{2}$ during human parturition and suggest that further clinical trials of $\mathrm{PGI}_{2}$-based therapeutics may be warranted.

While we noted a consistent response to $\mathrm{PGI}_{2}$ in all patient samples, the magnitude of the response varied. The range of responses is possibly due to the extent of myometrial activation that had occurred in each specimen in vivo prior to organ culture. We speculate that iloprost would exert a lesser effect in tissue that was partially or fully activated prior to organ culture, whereas tissue that had not yet undergone activation in vivo would demonstrate the greatest increase in contrac-

tility after iloprost treatment. As there is currently no way to accurately predict proximity to labor in patients, we cannot easily test this hypothesis. The degree of endogenous $\mathrm{PGI}_{2}$ produced by the tissue itself is also another critical variable. If a particular specimen produced large amounts of $\mathrm{PGI}_{2}$, then added $\mathrm{PGI}_{2}$ would have only minor effects on contractility. Thus interindividual variability in tissue samples could account for the range of effects that we observed in the contractility experiments.

Our study raises the intriguing question as to how $\mathrm{PGI}_{2}$ can play different roles at different times during pregnancy. We show here that $\mathrm{PGI}_{2}$ upregulation of contractile proteins and connexin 43 depends on a PKA signal. $\mathrm{PGI}_{2}$-dependent smooth muscle relaxation is also thought to be PKA dependent $(1,6)$. It is likely that multiple factors affect the ultimate outcome of the PKA signal. The ERK/MAPK pathway is the best-characterized example of how the biological outcome of signaling pathways depends upon context and timing. ERK activation can promote opposing outcomes such as proliferation or differentiation, depending on factors such as signal strength and duration, receptor density, extracellular matrix composition, expression of scaffolding proteins and cell type-specific transcription factors, and the presence of other incoming signals (cross-talk; reviewed in ref. 52). We hypothesize that, because of hormonal changes and other signals, the context for the $\mathrm{PGI}_{2}$ signal at the time of myometrial activation differs from its context earlier in pregnancy. It is known that steroid hormones play a major role in myometrial regulation (6) and that myometrial estrogen receptor levels and estrogen sensitivity are enhanced at term (53). Estrogen receptor, in turn, increases COX-2 expression $(53,54)$, which has also been implicated in stimulating myometrial activation (53). This elevated COX-2 may, at least in part, explain the increase in $\mathrm{PGI}_{2}$ levels that occurs at term (27). Elevated $\mathrm{PGI}_{2}$ levels could thus alter signal strength and duration, which could generate different effects of $\mathrm{PGI}_{2}$ at term. The number of hIPs is not known to change during the course of pregnancy (55), so the differential signaling may be mediated primarily at the level of ligand expression and/or potential cross-talk mechanisms described below.

The effects of estrogen and other hormonal changes near term may also induce other changes in cellular context, in which crosstalk caused by concomitant activation of other receptors alters the ultimate downstream effectors of the $\mathrm{PGI}_{2}$ signal. Our data suggest that $\mathrm{PGI}_{2}$ and oxytocin signaling may cooperatively induce contractile protein expression. We hypothesize that the different environment during the course of myometrial activation may also result in expression of transcription factors and cofac-
A

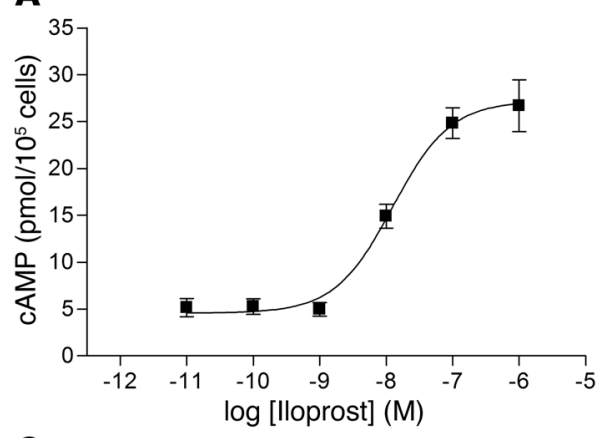

C

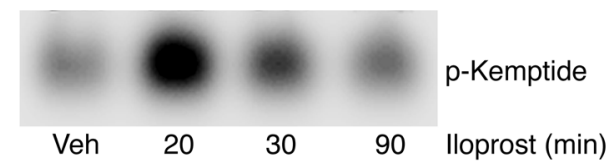

\section{Figure 8}

Iloprost induces CAMP/PKA activity in human uSMCs. (A) Concentration-response curves were determined by treating uSMCs with concentrations of iloprost ranging from $10 \mathrm{pmol} / \mathrm{l}$ to $1 \mu \mathrm{mol} / \mathrm{l}$. After $20 \mathrm{~min}$, cells were harvested, and cAMP was measured as described in Methods. Results are mean $\pm \mathrm{SEM}$. EC 50 was determined from best-fit curve with nonlinear regression. (B) Human uSMCs were treated with vehicle or the indicated concentrations of iloprost for $20 \mathrm{~min}$, and cell lysates were analyzed for PKA activity as described in Methods. A representative gel is shown. Fluorescence units of phosphorylated kemptide (p-Kemptide) were quantified by densitometry and expressed as fold induction. $n=5$ separate experiments. (C) Human uSMCs were treated with $2.5 \mathrm{nmol} / \mathrm{l}$ iloprost for the indicated times, and cells were harvested and analyzed for PKA activity. 
A

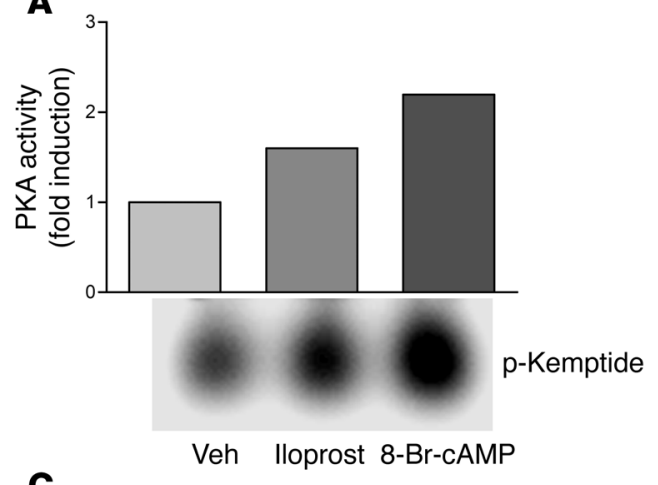

C

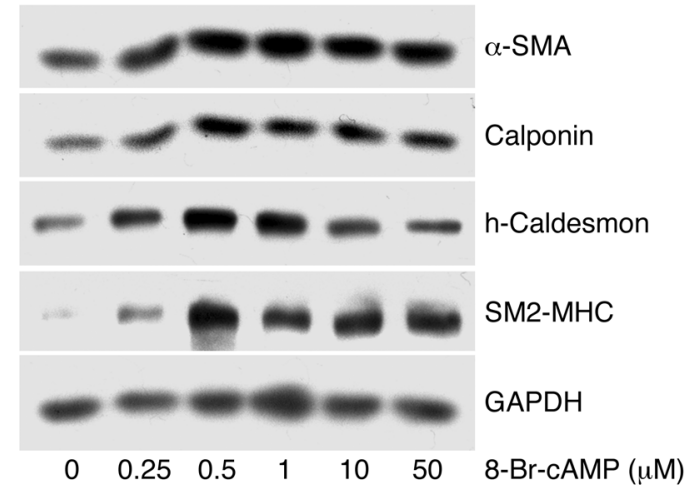

B

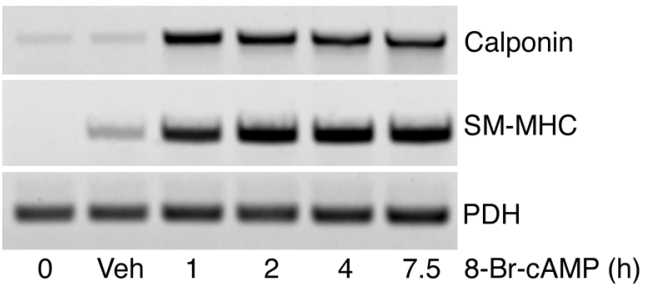

D

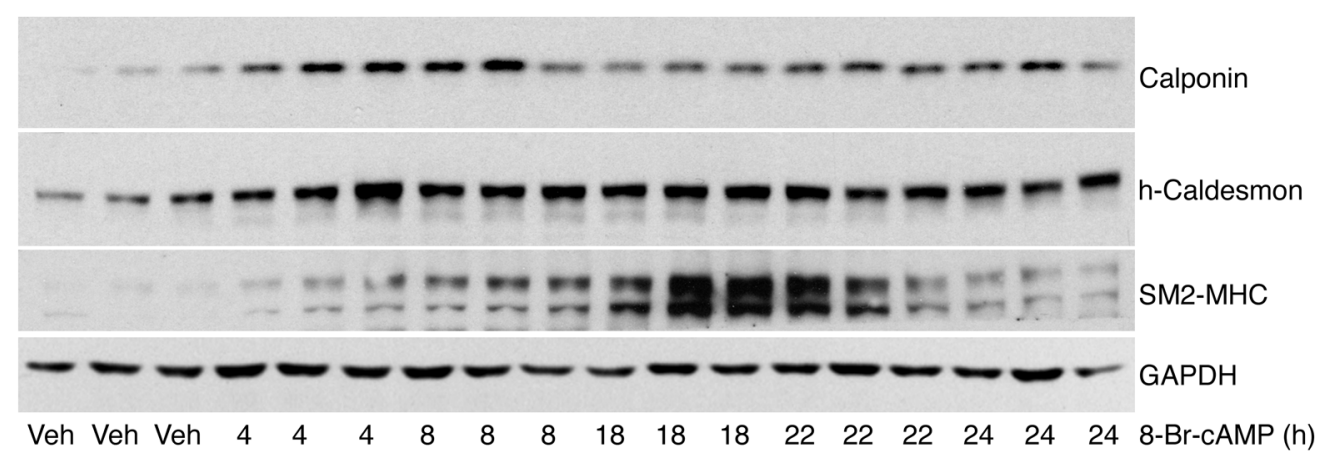

Figure 9

cAMP is sufficient to induce contractile protein expression. (A) Human uSMCs were treated with vehicle, $2.5 \mathrm{nmol} / \mathrm{l}$ iloprost, or $0.5 \mu \mathrm{mol} / \mathrm{l} 8-\mathrm{Br}$-cAMP for $20 \mathrm{~min}$, and cells were harvested and analyzed for PKA activity. Shown are a representative gel showing phosphorylated kemptide and densitometric quantitation of 2 independent experiments expressed as fold induction. Arithmetic mean values are shown. (B) Total RNA was isolated from human uSMCs at time point 0 , treated with vehicle for $7.5 \mathrm{~h}$, or treated with $0.5 \mu \mathrm{mol} / \mathrm{l} 8-\mathrm{Br}$-cAMP for the indicated times. RNA was subjected to RT-PCR using primers to the basic calponin, SM-MHC, or PDH genes. (C) Human uSMCs were treated with the indicated concentrations of 8-Br-cAMP for $8 \mathrm{~h}$, and cell lysates were subjected to Western blot analysis with antibodies to $\alpha$-SMA, calponin, h-caldesmon, SM2-MHC, and GAPDH. (D) Human uSMCs treated with vehicle or $0.5 \mu \mathrm{mol} / \mathrm{l} 8-\mathrm{Br}-\mathrm{cAMP}$ for the indicated times were harvested and subjected to Western blot analysis with antibodies to calponin, h-caldesmon, SM2-MHC, and GAPDH.

tors not present earlier in pregnancy. Our ongoing preliminary studies provide evidence that signaling through hIP activates and upregulates multiple transcription factors known to regulate contractile protein expression in smooth muscle, including some that are known to be regulated, at least in part, by calcium signaling (our unpublished observations). These findings suggest an avenue for cooperation between calcium-stimulating agonists such as oxytocin or $\mathrm{PGF}_{2 \alpha}$ with the PKA-activating $\mathrm{PGI}_{2}$ near term.

Effects on downstream transcription factors also likely explain the sustained effect elicited by single doses of either $\mathrm{PGI}_{2}$ or its analogs, which are all short-lived agonists. We showed that
PKA activation by iloprost or cicaprost was rapid and transient, peaking by $20 \mathrm{~min}$. Upregulation of contractile proteins and connexin 43 at the mRNA level was first detected at early time points (as early as $30 \mathrm{~min}$ for SM-MHC). The kinetics of contractile protein and connexin 43 protein expression followed those of the mRNA levels, and maximal increases were observed after 24-48 h. Thus, while an initial acute response to cAMP/ PKA may in fact be muscle relaxation, our data suggest that the transcriptional changes are also initiated early but result in longer-lived effects on protein expression. Changes in expression of contractile proteins and connexin 43 may be seen as a 
A

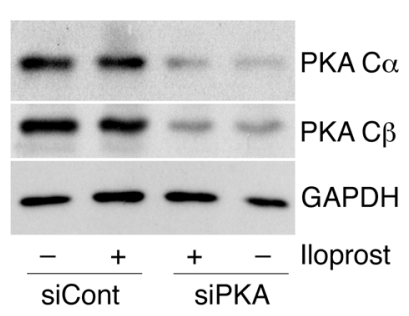

B

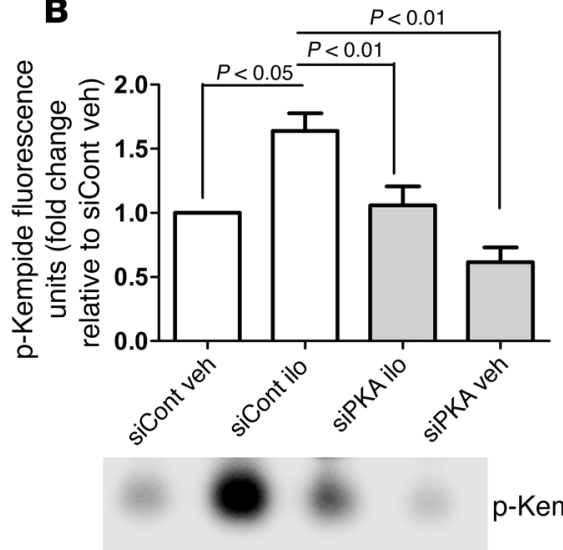

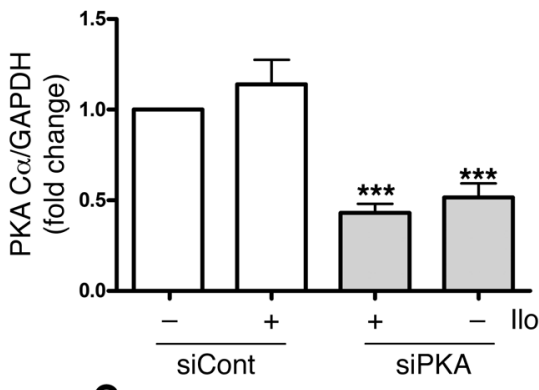

C
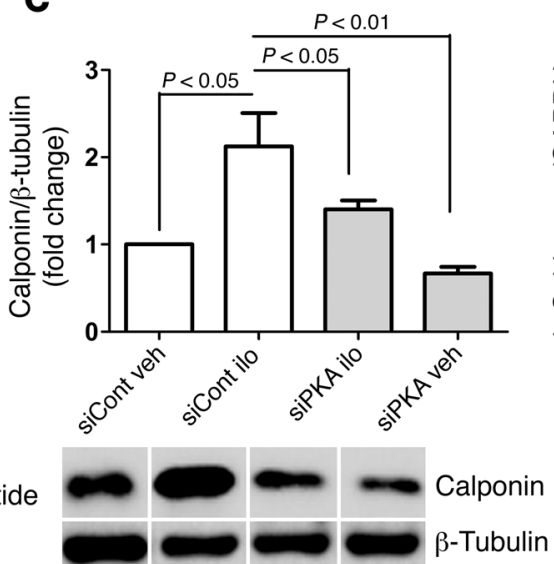

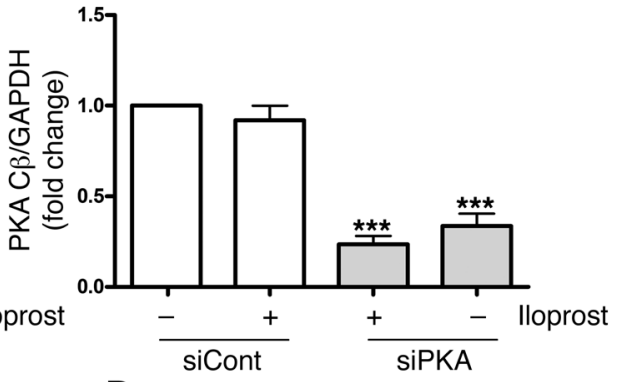

D

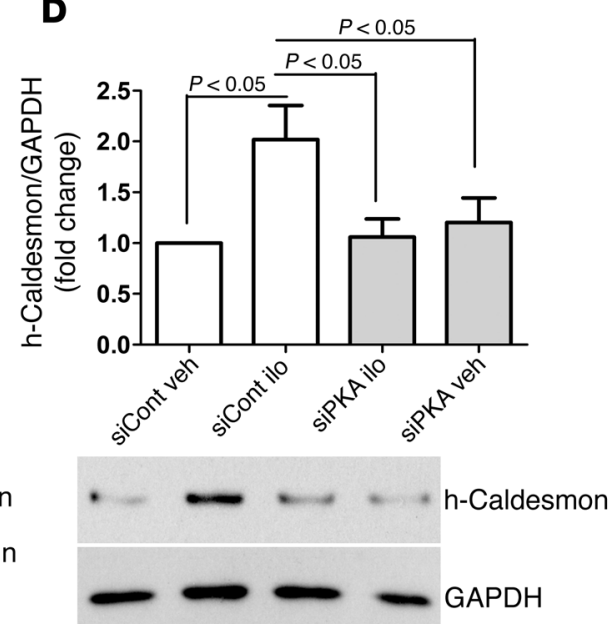

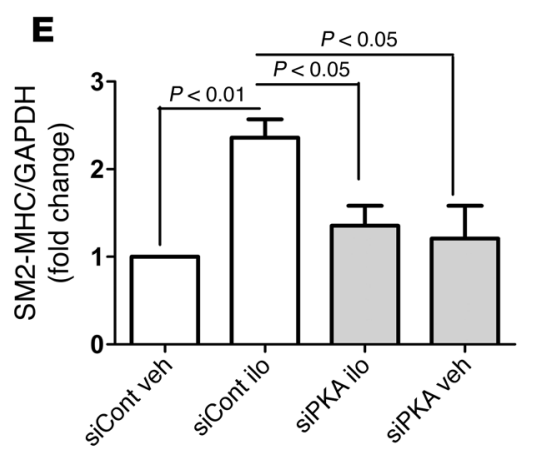

F

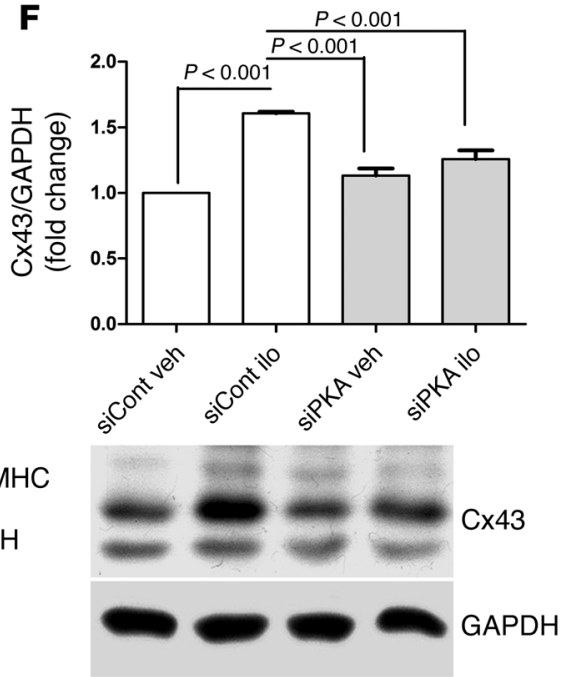

Figure 10

PKA is required for iloprost-induced contractile protein and connexin 43 expression. (A) Human uSMCs were transiently transfected with siRNA to PKA C $\alpha$ and PKA C $\beta$ (siPKA) or negative control siRNA, siControl (siCont). At $40 \mathrm{~h}$ after transfection, cells were treated with vehicle or $2.5 \mathrm{nmol} / \mathrm{l}$ iloprost for $8 \mathrm{~h}$, harvested, and subjected to Western blot analysis for PKA C $\alpha$ and PKA C $\beta$. Representative blots are shown. Amounts of PKA C $\alpha$ and PKA C $\beta$ proteins relative to GAPDH were quantified by densitometry ( $n=7$, including cell cultures derived from 2 different patient samples). ${ }^{\star * *} P<0.001$ versus vehicle- and iloprost-treated siControl. (B) Human uSMCs were transfected with PKA C $\alpha$ and PKA C $\beta$ (0.5 $\mu$ g each) or siControl for $48 \mathrm{~h}$ followed by treatment with vehicle or $2.5 \mathrm{nmol} / \mathrm{l}$ iloprost (ilo) for $20 \mathrm{~min}$. Cell lysates were analyzed for PKA activity as described in Methods. A representative gel is shown. Densitometric quantitation of fluorescence units of phosphorylated kemptide is expressed as fold induction relative to siControl treated with vehicle $(n=3)$. $(\mathbf{C}-\mathbf{F})$ Human uSMCs were transfected as in $\mathbf{A}$ and treated with vehicle or $2.5 \mathrm{nmol} / \mathrm{I}$ iloprost for $8 \mathrm{~h}$. Western blots for (C) calponin, (D) h-caldesmon, (E) SM2-MHC, and (F) connexin 43 are shown with $\beta$-tubulin or GAPDH loading controls. Lanes in $\mathbf{C}$ were run on the same gel but were noncontiguous (lines). Densitometric quantitation of at least 3 independent experiments, including cell cultures derived from 2 different patient samples, are expressed as fold induction corrected to the loading control. All data are mean \pm SEM. Significance of differences were determined using 1-way ANOVA with Newman-Keuls post-hoc test. 
A

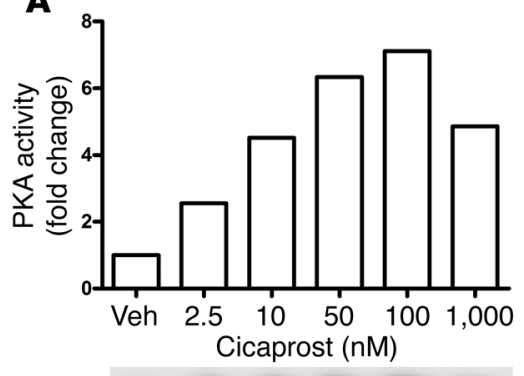

C

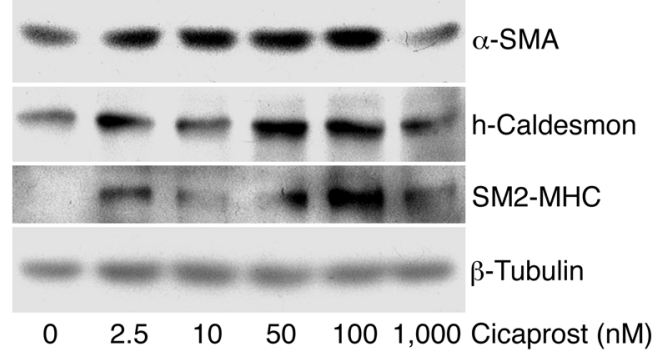

E

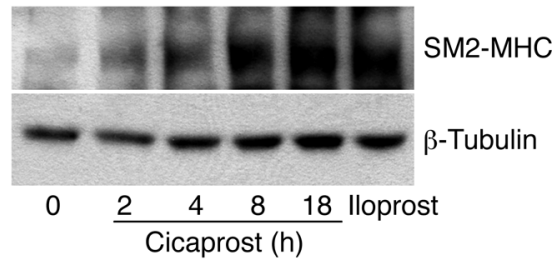

B

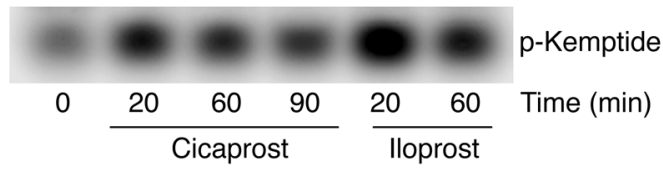

D

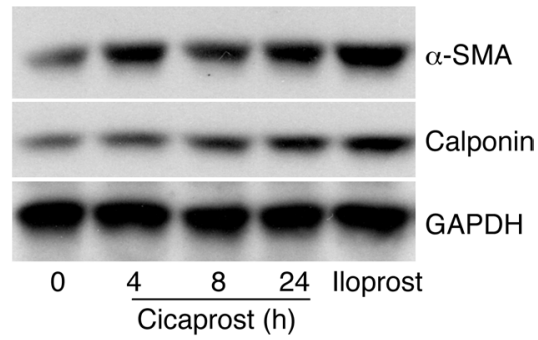

F

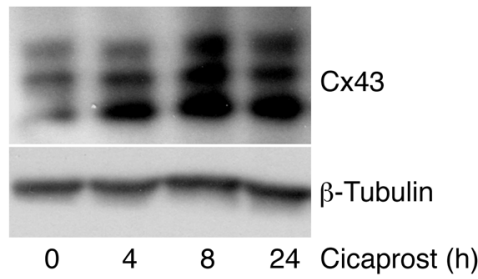

Figure 11

Cicaprost increases PKA activity as well as contractile protein and connexin 43 expression. (A) Human uSMCs were treated with vehicle or with the indicated concentrations of cicaprost for $20 \mathrm{~min}$. Cell lysates were analyzed for PKA activity as described in Methods. Densitometric quantitation of fluorescence units of phosphorylated kemptide from the gel shown are expressed as fold induction. (B) Human uSMCs were treated with $2.5 \mathrm{nmol} / \mathrm{I}$ cicaprost or iloprost for the indicated times, and cells were harvested and analyzed for PKA activity. The phosphorylated kemptide gel is shown. (C) Cell lysates from human uSMCs were treated with the indicated concentrations of cicaprost for $8 \mathrm{~h}$ and were subjected to Western blot analysis with antibodies to $\alpha$-SMA, h-caldesmon, SM2-MHC, and $\beta$-tubulin as a loading control. (D and E) Cells were treated with $2.5 \mathrm{nmol} / \mathrm{l}$ cicaprost for the indicated times or $2.5 \mathrm{nmol} / \mathrm{l}$ iloprost for $8 \mathrm{~h}$, and Western blots were performed using antibodies against (D) $\alpha$-SMA and calponin or (E) SM2-MHC. GAPDH and $\beta$-tubulin served as loading controls. (F) uSMCs were treated with $2.5 \mathrm{nmol} / \mathrm{l}$ cicaprost, and Western blot analysis was performed for connexin 43 and $\beta$-tubulin as a loading control.

priming event, whereby the myometrium is modified such that it becomes sensitized to respond to contractile stimuli - not only oxytocin (our present results), but possibly other PGs, such as $\mathrm{PGF}_{2 \alpha}$ - during labor.

Previous studies have demonstrated that at higher concentrations, $\mathrm{PGI}_{2}$ and some of its analogs, including iloprost and carbaprostacyclin, can regulate transcription by directly activating the nuclear receptors PPAR $\alpha$ or PPAR $\delta$ in a PKA-independent manner $(50,51)$. Our data do not support a major role for PPARs in upregulating contractile proteins or connexin 43, because RO3244794 or PKA inhibition opposed these effects, and the $\mathrm{PGI}_{2}$ analog cicaprost, which does not activate PPARs (50), mimicked the effects of iloprost.

The local concentrations of $\mathrm{PGI}_{2}$ achieved at term in human myometrium are unknown, because the very short half-life of this agonist precludes accurate measurements in real time. One study measured $\mathrm{PGI}_{2}$ produced by human myometrial tissue isolated at different time points (15-42 weeks) during pregnancy
(27). The findings from this study suggest that within a 30-min assay period, the isolated myometrial tissue can produce $\mathrm{PGI}_{2}$ concentrations of $0.4 \mu \mathrm{mol} / \mathrm{l}$ at 38 weeks and $1.6 \mu \mathrm{mol} / 1$ at 40 weeks, a 4 -fold increase. Given the short half-life ( $\sim 3 \mathrm{~min})$, the actual concentrations may be even higher locally in vivo. Notably, these concentrations are entirely consistent with those that we found to activate PKA and to induce contractile protein expression in our present studies $(0.6-6.0 \mu \mathrm{mol} / \mathrm{l})$. Furthermore, the doses of iloprost used in our study that potentiated contractility were fairly low, and concentrations below the $\mathrm{EC}_{50}$ for $\mathrm{cAMP} /$ PKA activation exerted potent effects on contractility and protein expression in vitro. It is likely that iloprost was more potent than $\mathrm{PGI}_{2}$ (600 nM PGI 2 was comparable to $2.5 \mathrm{nM}$ iloprost) because it is more stable (half-life of $\sim 30 \mathrm{~min}$ ) and therefore able to amplify signal over a longer period of time.

While relaxation induced by iloprost has been attributed to activation of cAMP/PKA signaling, exact mechanisms have yet to be elucidated. It is thought that PKA inhibits myosin light 
A

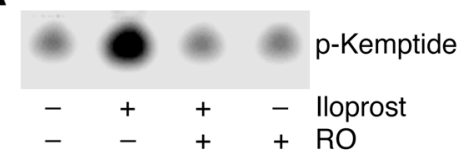

C

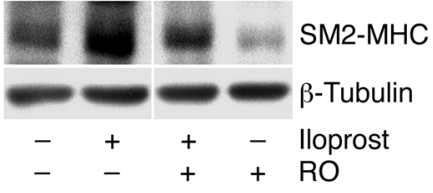

B

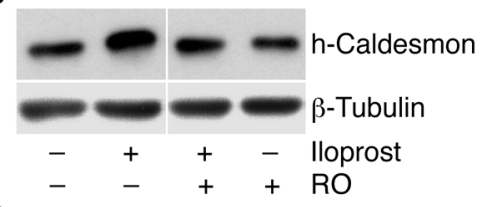

D

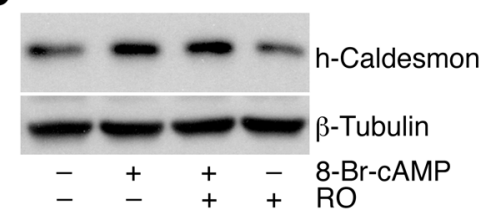

Figure 12

RO3244794 inhibits contractile protein expression induced by iloprost, but not by 8-Br-cAMP. (A) Human uSMCs were pretreated with $1 \mu \mathrm{M}$ RO3244794 for $30 \mathrm{~min}$ followed by treatment with vehicle or $2.5 \mathrm{nmol} / \mathrm{l}$ iloprost for $20 \mathrm{~min}$. Cell lysates were analyzed for PKA activity using a nonradioactive in vitro PKA assay. A representative experiment is shown. (B and $\mathbf{C}$ ) Human uSMCs were pretreated with $1 \mu \mathrm{M}$ RO3244794 for $30 \mathrm{~min}$ followed by treatment with or without $2.5 \mathrm{nmol} / \mathrm{l}$ iloprost for $8 \mathrm{~h}$. Cell lysates were prepared and subjected to Western blot analysis with antibodies against (B) h-caldesmon and (C) SM2-MHC. Lanes were run on the same gel but were noncontiguous (lines). (D) Human uSMCs were pretreated with $1 \mu \mathrm{M}$ RO3244794 for 30 min followed by treatment with $0.5 \mu \mathrm{M}$ 8-Br-cAMP for $8 \mathrm{~h}$. Cell lysates were subjected to Western blot analysis with antibodies against h-caldesmon and $\beta$-tubulin.

chain kinase (MLCK) (12), leading to inhibition of the interaction between actin and myosin. Consequently, agonists that stimulate cAMP/PKA signaling generally produce smooth muscle relaxation. In fact, $\beta$-adrenergic receptor ( $\beta$-AR) agonists, which activate cAMP/PKA, are currently used to inhibit uterine activity to prolong labor. Unfortunately, such drugs are only able to inhibit labor for up to $48 \mathrm{~h}$ (56). The short-lived effectiveness of $\beta$-AR agonists as tocolytic agents has been attributed to rapid receptor desensitization and internalization (57). Based on our present data, we speculate that these drugs may be only transiently effective because of eventual PKA-dependent regulation of contractile apparatus and gap junction proteins, priming the uterus for contraction.

Interestingly, IP knockout mice (54, 58-61) and PGI synthase knockout mice (62) have no reported defects in the initiation or progression of parturition. It is possible that contractile agonists, such as oxytocin, $\mathrm{PGF}_{2 \alpha}$, $\mathrm{PGE}_{2}$, and others, can eventually stimulate efficient contractions with basal levels of contractile proteins, or that other mechanisms compensate to upregulate these proteins in the absence of $\mathrm{PGI}_{2}$ signaling. Consistent with this, we noted a modest induction in contractile protein expression in response to oxytocin alone. While $\mathrm{PGI}_{2}$ agonists have been administered to pregnant women for treatment of pulmonary hypertension with no adverse effects (reviewed in ref. 63), none of these patients was treated with these agonists near term. One clinical study showed that urinary $\mathrm{PGI}_{2}$ metabolites were increased by $32 \%$ in women in preterm labor compared with controls (64), consistent with a potential role for $\mathrm{PGI}_{2}$ in labor onset. Significant differences in the physiology of labor in the mouse, both anatomically and hormonally, make extrapolation of murine genetic studies to human labor difficult. These differences, and the obvious ethical limits to conducting studies in pregnant human subjects, present challenges to advancing our understanding of human parturition and ability to develop bet- ter tocolytic therapies. Therefore, the use of pregnant human myometrial tissue near term, in organ and cell culture, is a particular strength of our study, allowing us to make further inroads into the molecular mechanisms underlying this crucial process.

In conclusion, we have shown that $\mathrm{PGI}_{2}$ signaling enhanced the contractile response of human pregnant myometrium to oxytocin and upregulated contractile apparatus protein expression and the gap junction protein connexin 43. Our results have important implications for a role of endogenous myometrial $\mathrm{PGI}_{2}$ as an important factor in regulating activation of the myometrium, a critical step in the initiation and progression of parturition.

\section{Methods}

Tissue procurement and culture. Tissue procurement was performed in accordance with a Dartmouth College Institutional Review Board-approved protocol (IRB protocol no. 15820). Myometrium was obtained as previously described (45), after obtaining informed consent, from women not in labor undergoing Cesarean section delivery between 37.5 and 41 weeks gestation for clinical indications. Indications include repeat Cesarean section and breech presentation. Specifically excluded were patients who were treated with magnesium sulfate, other tocolytic agents, or intravenous oxytocin or who exhibited signs of intrauterine infection. An excisional biopsy was obtained from the upper margin of the uterine incision after removal of the infant and placenta and control of bleeding. Tissue was stored and transported in DMEM supplemented with $10 \%$ FBS. Decidua and serosa were dissected from the tissue and discarded. Myometrial tissue strips, approximately $1 \times 1 \times 15 \mathrm{~mm}$, were cut along the lines of the fasciculata using sterile technique. Each end was secured with a 000 vicryl suture. Tissue strips were organ cultured as previously described (45). In brief, tissue strips were cultured by mounting each vertically in its own tube and maintained in culture at $37^{\circ} \mathrm{C}$, $5 \% \mathrm{CO}_{2}$, in DMEM. A 400-mg weight was suspended from each strip to apply constant tension. Using this technique, tissue strip contractility was routinely maintained for more than 7 days.

Contraction assays. Tissue strips were placed in 1 of 2 identical isometric contraction devices, and experiments were performed in pairs. Forces produced by each tissue were monitored using a Grass-Telefactor FT-03 force transducer. Output was monitored by an analog-to-digital converter and stored on a personal computer for later analysis. Using micrometer drives, tissues were stretched to $140 \%$ of resting length, and the physical distances were not adjusted again for the duration of the experiment. Initial tensions were usually on the order of $1-2 \mathrm{~g}$, which then fell due to viscoelastic creep to values of $\sim 500 \mathrm{mg}$. Spontaneous (e.g., applied tension only) contractions were sometimes observed, and at least 3 contractions were measured. After $30 \mathrm{~min}$ of observation, $5 \mathrm{nmol} / 1$ oxytocin was added to all tissues. In all cases, contractions were then observed, and at least 5 contractions were measured. Sample traces are shown in Figure 4B. For each contraction, peak forces were measured from the baseline to the peak of each contraction. For each experiment, contraction forces were averaged to yield average peak force production with standard deviations. At the conclusion of some experiments, $1 \mu \mathrm{M}$ A23187 was added to the bath to determine the maximal tension for each tissue.

Isolation of $m R N A$ and protein from uterine tissue strips. After treatment, tissue strips were washed in PBS, snap frozen, and stored at $-80^{\circ} \mathrm{C}$. To isolate protein and mRNA from the same tissue sample, $\mathrm{PBS}$ supplemented with 
A

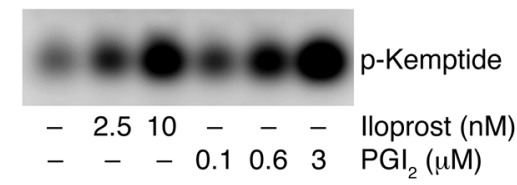

B

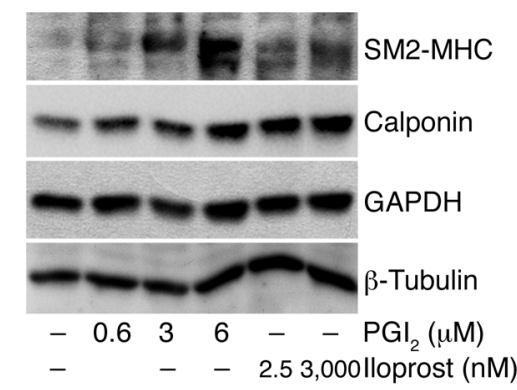

C

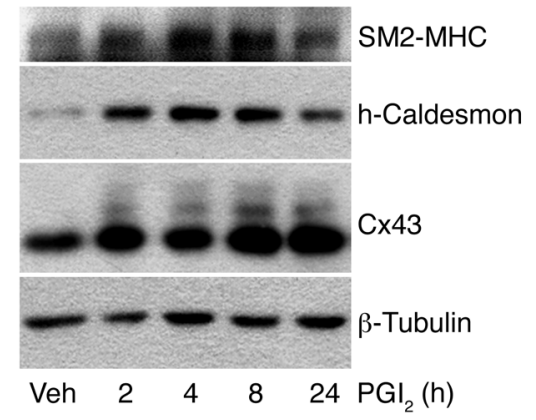

Figure 13

$\mathrm{PGI}_{2}$ mimics iloprost-induced contractile apparatus and connexin 43 protein expression. (A) Effect of PGI ${ }_{2}$ on PKA activity. Human uSMCs were treated for $20 \mathrm{~min}$ with $\mathrm{PGI}_{2}$ or iloprost at the concentrations indicated and subjected to in vitro PKA assay. The phosphorylated kemptide gel is shown. (B and $\mathbf{C}$ ) Effect of $\mathrm{PGI}_{2}$ on contractile apparatus protein and connexin 43 expression. (B) Human uSMCs were treated with $P G \mathrm{I}_{2}$ every $1.5 \mathrm{~h}$ up to $6 \mathrm{~h}$ or with a single treatment of iloprost for $6 \mathrm{~h}$ at the concentrations indicated. Western blots were performed with antibodies against SM2-MHC, calponin, $\beta$-tubulin, and GAPDH. (C) uSMCs were subjected to a single treatment of $0.6 \mu \mathrm{mol} / \mathrm{I} \mathrm{PGl_{2 }}$ for the indicated times. Western blot analysis was performed with antibodies against SM2-MHC, h-caldesmon, connexin 43, and $\beta$-tubulin as a loading control.

RNase inhibitor $(0.75 \mathrm{U} / \mu \mathrm{l}$; Ambion) and a complete protease inhibitors tablet (Roche) was added. Samples were sonicated on ice and then centrifuged at $4,000 \mathrm{~g}$ for $15 \mathrm{~min}$ at $4^{\circ} \mathrm{C}$. The protein-containing supernatant was collected. The pellet was resuspended in TRIzOL reagent (Invitrogen) to extract total RNA according to the manufacturer's protocol.

Cell culture. Human uSMCs were isolated from myometrial tissue obtained as described above. Cells were isolated by enzymatic digestion. In brief, tissue was minced and washed in HBSS. Tissue was digested in Collagenase XI and Collagenase IA (1 $\mathrm{mg} / \mathrm{ml}$ each; Sigma-Aldrich) in HBSS at $37^{\circ} \mathrm{C}$ for $1 \mathrm{~h}$, after which the cells were centrifuged and cultured in monolayer in DMEM supplemented with $10 \% \mathrm{FBS}$ at $37^{\circ} \mathrm{C}$. Passages 2-7 were used for experiments. Cultures derived from 4 different patients were used for experiments. All drug treatments were performed in DMEM containing 2.5\% FBS. Vehicle-treated cells were incubated with PBS for the maximum duration of the experimental treatment. Cells were treated with various drugs, as indicated in the figure legends. Iloprost was purchased from Amersham Biosciences. 8-Br-cAMP and oxytocin were purchased from Sigma-Aldrich. Cicaprost was a gift from Schering. The IP antagonist RO3244794 was a gift from M.-F. Jett (Roche, Palo Alto, California, USA).

Semiquantitative RT-PCR. Total RNA was isolated from monolayer cells using the Qiagen RNeasy kit with DNase I (Qiagen) and quantitated in duplicate by spectrophotometry. RNA $(0.8 \mu \mathrm{g})$ was reverse transcribed using MMLV RNase $\mathrm{H}^{+}$reverse transcriptase and oligo(dT) primers (Promega). Primers to specifically amplify the human SM-MHC gene transcript, human basic calponin gene transcript, and the pyruvate dehydrogenase (PDH) transcript (housekeeping control gene) were used as described previously (44). Primers were designed to amplify the human connexin 43 gene transcript: sense, 5'-TCATGTGCGCTTCTGGGTCCT3'; antisense, 5'-CCTTAACGCCCTTGAAGAAA-3'. A dilution series of the reverse-transcribed CDNA was used to determine the linear range of the PCR for each primer set. PCR was performed using 20 pmol of each primer, $0.04 \mathrm{mmol} / \mathrm{l} \mathrm{dNTPs}$, and HotMaster Taq DNA polymerase (Eppendorf). PCR with calponin or PDH primer sets was performed for 32 cycles of $95^{\circ} \mathrm{C}$ for $30 \mathrm{~s} ; 62^{\circ} \mathrm{C}$ (connexin 43 ), $58.5^{\circ} \mathrm{C}$ (calponin), or $55^{\circ} \mathrm{C}(\mathrm{PDH})$ for $30 \mathrm{~s}$; and $70^{\circ} \mathrm{C}$ for $1 \mathrm{~min}$. PCR with MHC primers was performed for 34 cycles of $95^{\circ} \mathrm{C}$ for $30 \mathrm{~s} ; 54^{\circ} \mathrm{C}$ for $30 \mathrm{~s}$; and $70^{\circ} \mathrm{C}$ for $1 \mathrm{~min}$. PCR products were resolved on $1 \%$ agarose gels with GelStar nucleic acid stain (Cambrex), and digital images were obtained using a Typhoon Scanner (Molecular Dynamics).
Cell lysis and immunoblotting. Cells were lysed for Western blot analysis as previously described (44). Bradford assay was used to determine total protein concentration (Pierce). Equal amounts of protein $(10-20 \mu \mathrm{g}$ ) from each lysate were subjected to Western blot analysis as described previously (44) using primary antibodies against $\alpha$-SMA, calponin, or h-caldesmon (Sigma-Aldrich); SM2-MHC (Seikagaku America); connexin 43 (Cell Signaling); PKA C $\alpha$, PKA C $\beta$, or $\beta$-tubulin (Santa Cruz Biotechnology Inc.); or GAPDH (AbCam). Signal was detected with enhanced chemiluminescence reagents (Pierce). Densitometry was performed using Scion Image Beta (version 4.0.2) to determine relative quantities of protein, with data then normalized to GAPDH or $\beta$-tubulin.

Determination of cAMP levels. At confluence, uSMCs in 12-well plates were incubated with DMEM containing 2.5\% FBS overnight. Cells were washed twice with PBS plus $4 \mathrm{mmol} / \mathrm{l}$ EDTA and $2 \mathrm{mmol} / 1$ isobutylmethylxanthine ( $\mathrm{pH} 7.4$ ) and incubated at $20^{\circ} \mathrm{C}$ for $10 \mathrm{~min}$. cAMP generated in response to defined concentrations of iloprost ( $10 \mathrm{pmol} / 1$ to $10 \mu \mathrm{mol} / 1$; 20 -min treatment) was measured using a radio-receptor competition assay (Amersham Biosciences) as described previously (44). Results were analyzed using GraphPad Prism version 4.0 software. For the concentration response, a nonlinear, curve-fitting program (GraphPad Prism, version 4.0) was used and the $\mathrm{EC}_{50}$ was determined.

Nonradioactive in vitro assay for PKA activity. We treated uSMCs as indicated in the figure legends. Cells were lysed as described previously (44), and total protein concentration in each lysate was determined by Bradford assay. Equal amounts of protein from each sample $(10-30 \mu \mathrm{g})$ were subjected to the PepTag Assay for Non-Radioactive Detection of cAMP Dependent Protein Kinase (Promega) using the fluorescence-labeled peptide substrate kemptide according to the manufacturer's protocol and as described previously (44). The phosphorylated and nonphosphorylated kemptide were separated on a $0.8 \%$ agarose gel, and an image was obtained using a Typhoon Scanner (Molecular Dynamics). Densitometry was used to determine the quantity of phosphorylated substrate using Scion Image Beta (version 4.0.2).

Transient transfection of siRNA. Human uSMCs (1-1.5 $\times 10^{6}$ cells) were transfected with siRNA using the basic SMC Nucleofector Solution and the Nucleofector Device (Amaxa). uSMCs were transfected with $0.5-0.65 \mu \mathrm{g}(52-68 \mathrm{pmol})$ PKA C $\alpha$ and $0.5-0.65 \mu \mathrm{g}$ PKA C $\beta$ siRNA or $1.0-1.3 \mu \mathrm{g}(80-104 \mathrm{pmol})$ siCONTROL for $48 \mathrm{~h}$. Cells were treated with vehicle or iloprost for $20 \mathrm{~min}$ or $8 \mathrm{~h}$ and harvested for PKA activity or Western blotting as described above. The sequence for PKA C $\alpha$ siRNA 
was $5^{\prime}$-AAGUGGUUUGCCACAACUGAC-3', and the siRNA sequence for PKA C $\beta$ was $5^{\prime}$-AAGAGUUUCUAGCCAAAGCCA-3' (Dharmacon). Microarray-validated nontargeting duplex siRNA (siCONTROL; Dharmacon) was used as a negative control.

Statistics. Unless otherwise indicated, data are mean \pm SEM. Densitometry results were analyzed using Prism software (version 4.0; GraphPad), and significance of differences was determined using 1-way ANOVA with posthoc Newman-Keuls test for multiple comparisons or 1-tailed Student's $t$ test. A $P$ value less than 0.05 was considered significant.

\section{Acknowledgments}

We thank Mary-Frances Jett for providing RO3244794. We thank Richard J. Powell for helpful comments. The authors are supported by NHLBI grant R01 HL074190 (to J. Hwa), by NHLBI grant
R01 HL76612 (to K.A. Martin), and by NIH grant T32 CA09658 (to K.M. Fetalvero).

Received for publication August 31, 2007, and accepted in revised form September 24, 2008.

Address correspondence to: Kathleen A. Martin, Dartmouth Medical School HB7850, Dartmouth-Hitchcock Medical Center, One Medical Center Drive, Lebanon, New Hampshire 03756, USA. Phone: (603) 650-7439; Fax: (603) 650-4928; E-mail: kathleen. a.martin@dartmouth.edu.

Roger C. Young's present address is: Department of Obstetrics and Gynecology, University of Vermont, Burlington, Vermont, USA.
1. Challis, J.R.G., Matthews, S.G., Gibb, W., and Lye, S.J. 2000. Endocrine and paracrine regulation of birth at term and preterm. Endocr.Rev. 21:514-550.

2. Condon, J.C., Jeyasuria, P., Faust, J.M., and Mendelson, C.R. 2004. Surfactant protein secreted by the maturing mouse fetal lung acts as a hormone that signals the initiation of parturition. Proc. Natl. Acad. Sci. U. S. A. 101:4978-4983.

3. Ellis, M.J., Livesey, J.H., Inder, W.J., Prickett, T.C., and Reid, R. 2002. Plasma corticotropin-releasing hormone and unconjugated estriol in human pregnancy: gestational patterns and ability to predict preterm delivery. Am. J. Obstet. Gynecol. 186:94-99.

4. McLean, M., et al. 1995. A placental clock controlling the length of human pregnancy. Nat. Med. 1:460-463.

5. Wolfe, C., Poston, L., and Jones, M. 1987. Digoxinlike immunoreactive factor, corticotropin-releasing factor, and pregnancy. Lancet. 1:335-336.

6. Hertelendy, F., and Zakar, T. 2004. Regulation of myometrial smooth muscle functions. Curr. Pharm. Des. 10:2499-2517.

7. Smith, R. 2007. Parturition. N. Engl. J. Med. 356:271-283.

8. Garfield, R.E., Sims, S., and Daniel, E.E. 1977. Gap junctions: their presence and necessity in myometrium during parturition. Science. 198:958-960.

9. Garfield, R.E., Thilander, G., Blennerhassett, M.G., and Sakai, N. 1992. Are gap junctions necessary for cell-to-cell coupling of smooth muscle?: An update. Can. J. Physiol. Pharmacol. 70:481-490.

10. Sakai, N., Tabb, T., and Garfield, R.E. 1992. Studies of connexin 43 and cell-to-cell coupling in cultured human uterine smooth muscle. Am. J. Obstet. Gynecol. 167:1267-1277.

11. Doring, B., et al. 2006. Ablation of connexin 43 in uterine smooth muscle cells of the mouse causes delayed parturition. J. Cell. Sci. 119:1715-1722.

12. Egarter, C.H., and Husslein, P. 1992. Biochemistry of myometrial contractility. Baillieres Clin. Obstet. Gynaecol. 6:755-769.

13. Takahashi, K., Hiwada, K., and Kokubu, T. 1986. Isolation and characterization of a 34,000-dalton calmodulin- and F-actin-binding protein from chicken gizzard smooth muscle. Biochem. Biophys. Res. Commun. 141:20-26.

14. Sobue, K., Muramoto, Y., Fujita, M., and Kakiuchi, S. 1981. Purification of a calmodulin-binding protein from chicken gizzard that interacts with F-actin. Proc. Natl. Acad. Sci. U. S. A. 78:5652-5655.

15. Cornwell, T.L., Li, J., Sellak, H., Miller, R.T., and Word, R.A. 2001. Reorganization of myofilament proteins and decreased cGMP-dependent protein kinase in the human uterus during pregnancy. J. Clin. Endocrinol. Metab. 86:3981-3988.

16. Word, R.A., Stull, J.T., Casey, M.L., and Kamm, K.E. 1993. Contractile elements and myosin light chain phosphorylation in myometrial tissue from nonpregnant and pregnant women. J. Clin. Invest.
92:29-37.

17. Riley, M., Baker, P.N., Tribe, R.M., and Taggart, M.J. 2005. Expression of scaffolding, signalling and contractile-filament proteins in human myometria: effects of pregnancy and labour. J. Cell. Mol. Med. 9:122-134.

18. March of Dimes PeriStats website. 2008. http:// www.marchofdimes.com/peristats/.

19. Esplin, M.S. 2006. Preterm birth: a review of genetic factors and future directions for genetic study. Obstet. Gynecol. Surv. 61:800-806.

20. Challis, J.R., et al. 2002. Prostaglandins and mechanisms of preterm birth. Reproduction. 124:1-17.

21. Hertelendy, F., and Zakar, T. 2004. Prostaglandins and the myometrium and cervix. Prostaglandins Leukot. Essent. Fatty Acids. 70:207-222.

22. Bennett, P.R., Elder, M.G., and Myatt, L. 1987. The effects of lipoxygenase metabolites of arachidonic acid on human myometrial contractility. Prostaglandins. 33:837-844.

23. Ritchie, D.M., Hahn, D.W., and McGuire, J.L. 1984. Smooth muscle contraction as a model to study the mediator role of endogenous lipoxygenase products of arachidonic acid. Life Sci. 34:509-513.

24. Wikland, M., Lindblom, B., and Wiqvist, N. 1984. Myometrial response to prostaglandins during labor. Gynecol. Obstet. Invest. 17:131-138.

25. Wiqvist, N., Lindblom, B., Wikland, M., and Wilhelmsson, L. 1983. Prostaglandins and uterine contractility. Acta Obstet. Gynecol. Scand. Suppl. 113:23-29.

26. Abel, M.H., and Kelly, R.W. 1979. Differential production of prostaglandins within the human uterus. Prostaglandins. 18:821-828.

27. Bamford, D.S., Jogee, M., and Williams, K.I. 1980. Prostacyclin formation by the pregnant human myometrium. Br. J. Obstet. Gynaecol. 87:215-218.

28. Omini, C., Folco, G.C., Pasargiklian, R., Fano, M., and Berti, F. 1979. Prostacyclin (PGI2) in pregnant human uterus. Prostaglandins. 17:113-120.

29. Korita, D., et al. 2004. 17beta-estradiol up-regulates prostacyclin production in cultured human uterine myometrial cells via augmentation of both cyclooxygenase- 1 and prostacyclinsynthase expression. J. Soc. Gynecol. Investig. 11:457-464

30. Ylikorkala, O., Makarainen, L., and Viinikka, L. 1981. Prostacyclin production increases during human parturition. Br. J. Obstet. Gynaecol. 88:513-516.

31. Ylikorkala, O., Paatero, H., Suhonen, L., and Viinikka, L. 1986. Vaginal and abdominal delivery increases maternal urinary 6-keto-prostaglandin F1 alpha excretion. Br. J. Obstet. Gynaecol. 93:950-954.

32. Omini, C., Pasargiklian, R., Folco, G.C., Fano, M., and Berti, F. 1978. Pharmacological activity of PGI2 and its metabolite 6-oxo-PGF1alpha on human uterus and fallopian tubes. Prostaglandins. 15:1045-1054.

33. Boie, Y., et al. 1994. Cloning and expression of A Cdna for the human prostanoid Ip receptor. J. Biol.
Chem. 269:12173-12178.

34. Namba, T., et al. 1994. cDNA cloning of a mouse prostacyclin receptor. Multiple signaling pathways and expression in thymic medulla. J. Biol. Chem. 269:9986-9992.

35. Tateson,J.E., Moncada, S., and Vane,J.R. 1977. Effects of prostacyclin (Pgx) on cyclic-amp concentrations in human platelets. Prostaglandins. 13:389-397.

36. Korita, D., et al. 2002. Cyclic mechanical stretch augments prostacyclin production in cultured human uterine myometrial cells from pregnant women: possible involvement of up-regulation of prostacyclin synthase expression. J. Clin. Endocrinol. Metab. 87:5209-5219.

37. Armstrong, J.M., Lattimer, N., Moncada, S., and Vane, J.R. 1978. Comparison of the vasodepressor effects of prostacyclin and 6-oxo-prostaglandin F1alpha with those of prostaglandin E2 in rats and rabbits. Br. J. Pharmacol. 62:125-130.

38. Dusting, G.J., Moncada, S., and Vane, J.R. 1977. Prostacyclin (PGX) is the endogenous metabolite responsible for relaxation of coronary arteries induced by arachindonic acid. Prostaglandins. 13:3-15.

39. Gryglewski, R.J., Bunting, S., Moncada, S., Flower, R.J., and Vane, J.R. 1976. Arterial walls are protected against deposition of platelet thrombi by a substance (prostaglandin X) which they make from prostaglandin endoperoxides. Prostaglandins. 12:685-713.

40. Omini, C., Moncada, S., and Vane, J.R. 1977. The effects of prostacyclin (PGI2) on tissues which detect prostaglandins (PG'S). Prostaglandins. 14:625-632.

41. Williams, K.I., El Tahir, K.E., and Marcinkiewicz, E. 1979. Dual actions of prostacyclin (PGI2) on the rat pregnant uterus. Prostaglandins. 17:667-672.

42. Senior, J., Marshall, K., Sangha, R., and Clayton, J.K. 1993. In vitro characterization of prostanoid receptors on human myometrium at term pregnancy. Br. J. Pharmacol. 108:501-506.

43. Wikland, M., Lindblom, B., Hammarstrom, S., and Wiqvist, N. 1983. The effect of prostaglandin I on the contractility of the term pregnant human myometrium. Prostaglandins. 26:905-916.

44. Fetalvero, K.M., et al. 2006. The prostacyclin receptor induces human vascular smooth muscle cell differentiation via the protein kinase A pathway. Am. J. Physiol. Heart Circ. Physiol. 290:H1337-H1346.

45. Young, R.C., and Zhang, P. 2004. Tissue-level bioelectrical signals as the trigger for uterine contractions in human pregnancy. J. Soc. Gynecol. Investig. 11:478-482.

46. Kiriyama, M., et al. 1997. Ligand binding specificities of the eight types and subtypes of the mouse prostanoid receptors expressed in Chinese hamster ovary cells. Br. J. Pharmacol. 122:217-224.

47. Abramovitz, M., et al. 2000. The utilization of recombinant prostanoid receptors to determine the affinities and selectivities of prostaglandins and related analogs. Biochim. Biophys. Acta. 
1483:285-293.

48. Bley, K.R., et al. 2006. RO1138452 and RO3244794: characterization of structurally distinct, potent and selective IP (prostacyclin) receptor antagonists. Br. J. Pharmacol. 147:335-345.

49. Sibley, D.R., and Lefkowitz, R.J. 1985. Molecular mechanisms of desensitization using the betaadrenergic receptor-coupled adenylate cyclase system as a model. Nature. 317:124-129.

50. Forman, B.M., Chen, J., and Evans, R.M. 1997. Hypolipidemic drugs, polyunsaturated fatty acids, and eicosanoids are ligands for peroxisome proliferator-activated receptors alpha and delta. Proc. Natl. Acad. Sci.U. S. A. 94:4312-4317.

51. Pola, R., et al. 2004. Comparative analysis of the in vivo angiogenic properties of stable prostacyclin analogs: a possible role for peroxisome proliferatoractivated receptors. J. Mol. Cell. Cardiol. 36:363-370.

52. Murphy, L.O., and Blenis, J. 2006. MAPK signal specificity: the right place at the right time. Trends Biochem. Sci. 31:268-275.

53. Smith, R., Mesiano, S., and McGrath, S. 2002. Hor- mone trajectories leading to human birth. Regul. Pept. 108:159-164.

54. Egan, K.M., et al. 2004. COX-2-derived prostacyclin confers atheroprotection on female mice. Science. 306:1954-1957.

55. Leonhardt, A., Glaser, A., Wegmann, M., Hackenberg, R., and Nusing, R.M. 2003. Expression of prostanoid receptors in human lower segment pregnant myometrium. Prostaglandins Leukot. Essent. Fatty Acids. 69:307-313.

56. Anotayanonth, S., Subhedar, N.V., Garner, P., Neilson, J.P., and Harigopal, S. 2004. Betamimetics for inhibiting preterm labour. Cochrane Database Syst. Rev. CD004352. doi:10.1002/14651858. CD004352.pub2.

57. Yaju, Y., and Nakayama, T. 2006. Effectiveness and safety of ritodrine hydrochloride for the treatment of preterm labour: a systematic review. Pharmacoepidemiol. Drug Saf. 15:813-822.

58. Cheng, Y., et al. 2002. Role of prostacyclin in the cardiovascular response to thromboxane $\mathrm{A}(2)$. Science. 296:539-541.
59. Kobayashi, T., et al. 2004. Roles of thromboxane $\mathrm{A}(2)$ and prostacyclin in the development of atherosclerosis in apoE-deficient mice. J. Clin. Invest. 114:784-794.

60. Murata, T., et al. 1997. Altered pain perception and inflammatory response in mice lacking prostacyclin receptor. Nature. 388:678-682.

61. Austin, S., and FitzGerald, G.A. 1999. Not a mouse stirring: deletion of the EP2 and love's labor's lost. J. Clin. Invest. 103:1481-1482.

62. Yokoyama, C., et al. 2002. Prostacyclin-deficient mice develop ischemic renal disorders, including nephrosclerosis and renal infarction. Circulation. 106:2397-2403

63. Huang, S., and Desantis, E.R.H. 2007. Treatment of pulmonary arterial hypertension in pregnancy. Am. J. Health Syst. Pharm. 64:1922-1926.

64. Kurki, T., Viinikka, L., and Ylikorkala, O. 1992. Urinary excretion of prostacyclin and thromboxane metabolites in threatened preterm labor: effect of indomethacin and nylidrin. Am. J. Obstet. Gynecol. 166:150-154 